\title{
Gold Catalyzed Oxycyclizations of Alkynols and Alkynediols
}

Benito Alcaide ${ }^{* a}$, Pedro Almendros ${ }^{* b}$ and José Miguel Alonso

Alkynols and alkynediols represent excellent building blocks for oxycyclization reactions, leading to a large number of different cyclic structures in one single step. Recently, the use of gold salts and gold complexes has been introduced as an alternative to the traditional methods, providing mild reaction conditions and high group compatibility. This overview focuses on the most recent achievements on gold-catalyzed oxycyclizations, both from alkynols and alkynediols, and their use in different cascade processes and total synthesis. 

Benito Alcaide was born in Aldea del Rey, Ciudad Real, Spain, in 1950. He received his B.S. degree (1972) and Ph.D. degree (1978) from the Universidad Complutense de Madrid (UCM) 5 under the supervision of Professor Franco Fernández. After a 4year period working on the chemistry of $\alpha$-iminoketones and related compounds, he began working on $\beta$-lactam chemistry. In 1984 he assumed a position of Associate Professor of Organic Chemistry and in 1990 was promoted to Full Professor at the ${ }_{10}$ UCM. His current recent interests include $\beta$-lactam chemistry, asymmetric synthesis of compounds of biological interest, free radicals, cycloaddition reactions, allenes, metal-promoted cyclizations, C-C coupling reactions, and organocatalysis.

Pedro Almendros was born in Albacete (Spain) in 1966. He 15 received his $B$. S. degree (1989) and his Ph. D. degree (1994) from the Universidad de Murcia under the supervision of Profs. Molina and Fresneda. After three years (1995-1998) postdoctoral work with Prof. Eric J. Thomas ( University of Manchester), supported by two postdoctoral grants (Spanish 20 MEC and European Marie Curie), he joined the research group of Prof. Benito Alcaide (UCM, Madrid) in 1998 as Associate Researcher (Contrato de Reincorporación de Doctores y Tecnólogos). Subsequent appointments have included Assistant Professor at the UCM (2000-2002), and Científico Titular 25 (Tenured Scientist) at the Instituto de Química Orgánica General, CSIC, Madrid. In 2007 he was promoted to Investigador Científico (Research Scientist) at the IQOG, CSIC, Madrid. He has co-authored over 120 research publications and 12 book chapters. Pedro has a Hirsch's index $h=30$. His research 30 interest includes $\beta$-lactam chemistry, allene chemistry, asymmetric synthesis, metal-promoted heterocyclizations, and $C-C$ coupling reactions.

José Miguel Alonso was born in Madrid (Spain) in 1975. He received his $B$. S. degree (1998) and his Ph. D. degree (2003)

${ }_{35}$ from the Universidad Complutense de Madrid, under the supervision of Prof. Benito Alcaide and Dr. Pedro Almendros. After several years working for the industry, he joined the research group of Prof. Enrique Guitián at Universidade de Santiago de Compostela (Spain, 2009), and later he rejoined 40 Benito Alcaide's research group where he is currently working as researcher (2010, Contrato de Apoyo a la Investigación de la Comunidad de Madrid). His research interest includes $\beta$-lactam chemistry, allene chemistry, asymmetric synthesis and metalpromoted heterocyclizations.

\section{${ }_{45}$ 1. Introduction}

During the last decade, the number of reactions catalyzed by gold complexes has experienced a dramatic growth. ${ }^{1}$ Due to the powerful soft Lewis acidic nature of these catalysts and their exceptional alkynophilicity, that allow surprisingly 50 mild reaction conditions, gold-oxycyclization of alkynols and alkynediols have concretely become a hot topic in current organic chemistry.

In most cases, the initial step is the activation of the alkyne by the metal catalyst, followed by the nucleophilic attack of 55 the hydroxylic group. Thus, a wide range of interesting structures can be achieved by this methodology, such as furans, ${ }^{2}$ dihydrofurans, ${ }^{3}$ pyrans, ${ }^{4}$ furanones ${ }^{5}$ or ketals, ${ }^{6}$ among many other heterocyclic systems and naturally ocurring structures.

\section{${ }_{60}$ 2. Gold-catalyzed oxycyclization in alkynols}

\subsection{Single cycloisomerization processes}

Tetrahydrofurans ${ }^{7}$ and pyrans represent a crucial target in organic chemistry because of their recurring presence in several natural structures. A large number of methodologies 65 have been described for their synthesis, and among them, metal based cycloisomerization of alkynols is one of the most convenient. High efficiency, atom economy and mild reaction conditions are just a few reasons to follow this strategy, and the obtention of products resulting through a 70 exo-dig and/or endo-dig process has been widely reported (Scheme 1).

After the earlier versions using different transition metal catalysts, such as palladium, silver, chromium or tungsten, ${ }^{8}$ gold salts and gold complexes have emerged as effective 75 catalysts for this kind of cycloisomerization.

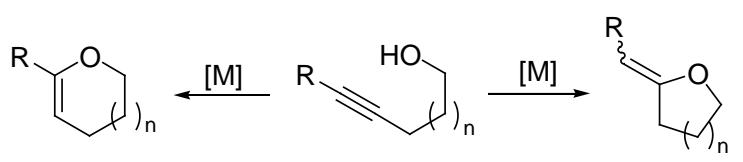

endo-dig pathway

exo-dig pathway

Scheme 1. Synthesis of dihydrofurans, pyrans and analogous 80 through endo-dig rearrangement, and tetrahydrofurans, tetrahydropyrans and relates systems through exo-dig process.

After studying the electronic effects on silver-catalyzed cycloisomerization, ${ }^{9}$ Pale and coworkers reported the change of catalyst to gold salts, trying to achieve a general 85 and more effective methodology for the synthesis of methylene oxolanes from simple terminal alkynols $\mathbf{1}^{10}$ Although the first decribed examples with unsubstituted acetylenic alcohols failed, they found that the use of $\mathrm{AuCl}$ together with $\mathrm{K}_{2} \mathrm{CO}_{3}$ worked efficiently at least on activated 90 systems. More interestingly, it was reported for the 5-exodig adducts 2 a complete selectivity, which was explained through the reaction mechanism noted below (Scheme 2). The observed regio- and stereoselectivity was rationalized through a first coordination of the alkyne motif by the gold

95 (I) ion, followed by a nucleophilic addition of the hydroxylic group in an anti auration process, generating intermedia A. ${ }^{11}$ Deprotonation promoted by $\mathrm{K}_{2} \mathrm{CO}_{3}$, and $\mathrm{C}-\mathrm{Au}$ bond hydrolysis would finally led to the observed final tetrahydrofurans 2 .

100

105 


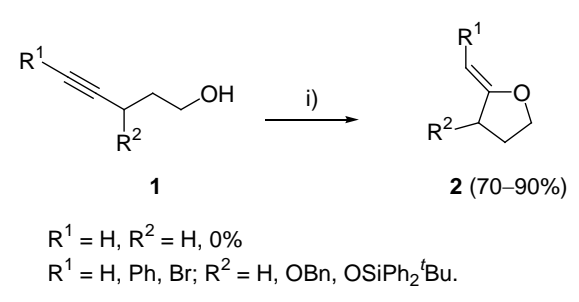

Reaction Mechanism

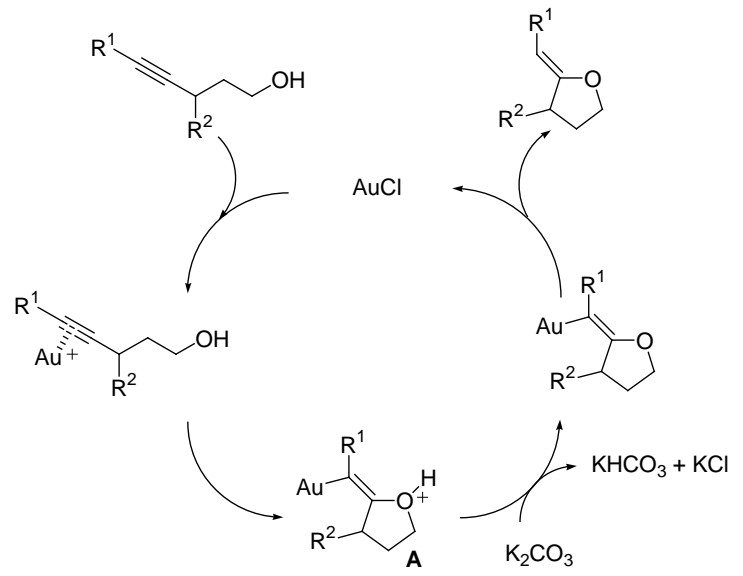

Scheme 2: $\mathrm{AuCl} / \mathrm{K}_{2} \mathrm{CO}_{3}$ catalyzed cycloisomerization of alkynols and proposed reaction mechanism. i) $\mathrm{AuCl}(0.1 \mathrm{eq}), \mathrm{K}_{2} \mathrm{CO}_{3}$ (0.1 5 eq), MeCN, rt, 1-3 h.

The scope of the process was also extended giving one example of a 6-membered oxane. Despite the lack of generality from a structural point of view, the selective 10 obtention of $Z$ isomers and exo-dig adducts through a very simple experimental procedure is the more remarkable feature of the work.

Recently, an identical methodology has been applied by Manzo and coworkers for the synthesis of substituted 15 benzoxazines. ${ }^{12} \quad$ Starting from 2-(prop-2-yn-1ylamino)phenols and employing the same dual catalyst system $\left(\mathrm{AuCl} / \mathrm{K}_{2} \mathrm{CO}_{3}\right)$, an interesting family of this fused six-membered heterocycle was obtained, exhibiting a complete exo-selectivity, but a less effective $Z / E$ ratio.

${ }_{20}$ Pyne et al. also tested gold salts among different catalysts for the synthesis of furo[3,2-a]pyrroles 5 and furo[3,2b]pyridines $\quad$ 6. $^{13}$ Starting from cis-4-hydroxy-5alkynylpyrrolidinones and cis-5-hydroxy-6-alkynylpiperidinones $\mathbf{3}$ and $\mathbf{4}$, cycloisomerization occurred in high 25 yields in most experiments (Scheme 3). In this case, Au (I) catalyst did not provide any advantage compared to Ag (I) or $\mathrm{Pd}(\mathrm{II}) / \mathrm{Cu}(\mathrm{I})$ salts, which made the reaction faster and the conversion higher. Nevertheless, it is worhy to note how cycloisomerization took place selectively, yielding 30 dihydrofuran systems in every case.

More interestingly, other similar fused bicyclic heteroatomic structures were obtained by Kerwin et al. under Au-catalysis as the best reaction conditions. ${ }^{14}$ Employing only 2 mol\% of metal salt, compared to even 30
35 mol\% for Pyne's substrates, they got access to imidazo[1,2c]-oxazoles 8 in excellent yields. Moreover, a dual behaviour for 1-alkynilimidazoles 7 was reported. These hydroxyacetylenic systems reacted in a regiospecific manner through a 6-endo-dig pathway in the presence of 40 metal catalyst, and through 5-exo-dig pathway under basic conditions yielding structures $\mathbf{9}$ (Scheme 3).

$$
\begin{aligned}
& \text { Pyne's report } \\
& \mathrm{n}=1,2 ; \mathrm{X}=\mathrm{O}, \mathrm{H}_{2} ; \mathrm{R}^{1}=\mathrm{Bn}, \mathrm{Cbz}, \mathrm{PMB} \text {. }
\end{aligned}
$$

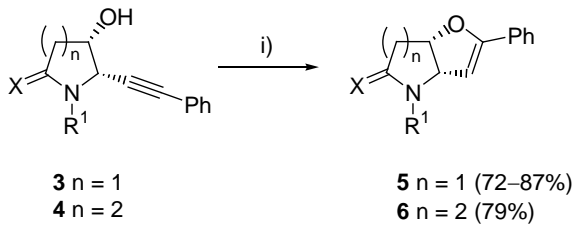

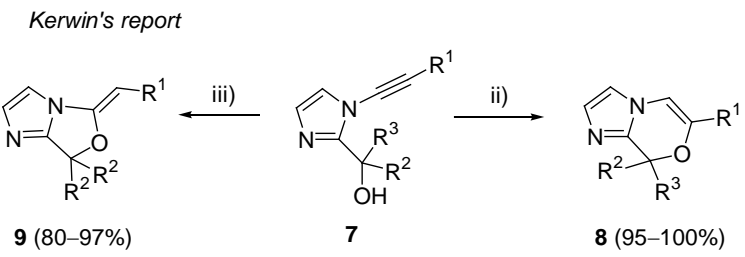

$$
\mathrm{R}^{1}=\mathrm{Ph}, p^{-}{ }^{\mathrm{B}} \mathrm{BuPh} ; \mathrm{R}^{2}=\mathrm{H}, \mathrm{Et} ; \mathrm{R}^{3}=\mathrm{Ph}, \mathrm{Et} .
$$

Scheme 3: Cycloisomerization reactions to yield fused bicyclic 45 heterocycles. i) $\mathrm{Au}\left(\mathrm{PPh}_{3}\right) \mathrm{Cl}(17-30 \% \mathrm{~mol}), \mathrm{EtOH}, 65-70^{\circ} \mathrm{C}, 8 \mathrm{~h}-5$ days. ii) $\mathrm{AuCl}_{3}$ (2\% mol), $\mathrm{CH}_{3} \mathrm{CN}$, reflux, 14h. iii) $\mathrm{K}_{3} \mathrm{PO}_{4}(5 \%$ mol), $\mathrm{CH}_{3} \mathrm{CN}$, reflux, $14 \mathrm{~h}$.

Czekelius and coworkers recently described an example 50 where the competition between exo and endo cyclization could be totally controlled, obtaining selectively both of the two possibilities. ${ }^{15}$ Starting from 3,3-disubstituted 1,4diynes 10 they found that only one isomer was obtained, exo or endo, depending on the experimental procedure (Scheme ${ }_{55} 4$ ). After going through different reaction conditions, checking several solvents and catalysts, they concluded that the nature of the group at the $\mathrm{C} 3$ position of diynes $\mathbf{1 0}$ was the only responsable of this selectivity. Thus, when an alcoxy group was located at this position, only endo-isomers

6011 were obtained. On the contrary, when an aliphatic chain was present at the $\mathrm{C} 3$ position of the corresponding 1,4diynes, only exo-isomers 12 were obtained. The same complete selectivy was observed even changing the length of the hydroxylic substituent. Czekelius et al also reported a 65 mechanistic proposal for this divergent behaviour, suggesting a possible coordination between the oxygen at the C3 position and the gold catalyst, as the main factor to set a different reaction pathway. 


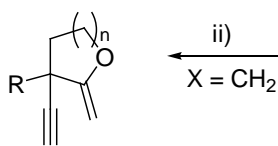

$12(62-99 \%)$
10

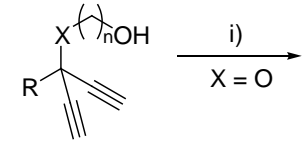

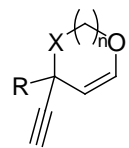

$11(30-88 \%)$ exo-cyclization

endo-cyclization

$\mathrm{R}=\mathrm{Bn}, \mathrm{Ph}, \mathrm{Cy}, \mathrm{PMP}, \mathrm{Tol}, \mathrm{p}-\mathrm{CF}_{3}-\mathrm{Ph} ; \mathrm{n}=1,2$.

Scheme 4: exo vs endo cycloisomerization in 1,4-diynols. i) $\left(\mathrm{Ph}_{3} \mathrm{P}\right) \mathrm{AuCl}$ (5 mol\%), $\mathrm{AgBF}_{4}$ (4 mol\%), THF, rt, 1-2 h. ii) $\left(\mathrm{Cy}_{3} \mathrm{P}\right) \mathrm{AuCl}, \mathrm{AgBF}_{4}$, Toluene, rt, 1-2 h.

Gold salts can also catalyze a different kind of cycloisomerization, apart from the most commonly studied endo-dig and exo-dig rearrangements. De Brabander and coworkers reported the cycloetherification of $\omega$-hydroxy 10 propargylic acetates 13, and their different reactivity depending on the nature of the metal catalyst. ${ }^{16}$ Thus, when $\mathrm{AuCl}$ was employed oxacyclic enol acetates 14 were formed, while the change to $\mathrm{Pt}(\mathrm{II})$ complex surprinsingly led to compound $\mathbf{1 5}$ through an unprecedent $\mathrm{S}_{\mathrm{N}} 2$ allenic 15 substitution (Scheme 5).

Paying attention first to the gold experiments, we can enjoy a general methodology for the obtention of oxygen containing heterocycles, with $5 \mathrm{~mol} \% \mathrm{AuCl}$ as the optimal catalyst reported for this transformation. Moreover, going 20 through the wide range of starting hydroxy propargylic esters, a good Z-selectivity on the final alkenes, an interesting protecting groups compatibility, and retention of the configuration on diastereomerically pure substrates, such as $\omega$-hydroxyproparylic acetate $\mathbf{1 6}$, can be stated.

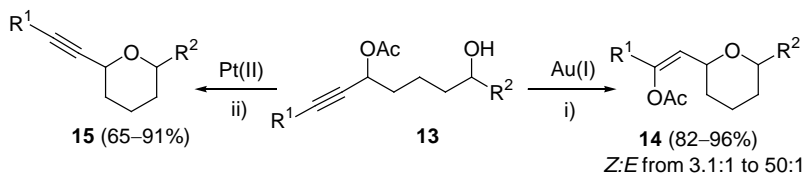

$\mathrm{R}^{1}=-\left(\mathrm{CH}_{2}\right)_{2} \mathrm{Ph},-\left(\mathrm{CH}_{2}\right)_{2} \mathrm{OTBDPS},-\left(\mathrm{CH}_{2}\right)_{4} \mathrm{OTBDPS}, \mathrm{Ph},-\left(\mathrm{CH}_{2}\right)_{5} \mathrm{Me} ; \mathrm{R}^{2}=\mathrm{H}, \mathrm{Et}$, i-Pr, $\mathrm{CH}_{2} \mathrm{CO}_{2} \mathrm{Et}$.
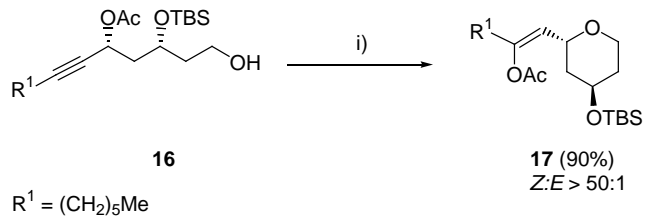

25

Scheme 5: Cycloetherification process catalyzed by $\mathrm{Au}(\mathrm{I})$ and $\mathrm{Pt}(\mathrm{II})$. i) $\mathrm{AuCl}$ (5\% mol), THF, rt, $30 \mathrm{~min}$. ii) $\left[\mathrm{Cl}_{2} \mathrm{Pt}\left(\mathrm{CH}_{2} \mathrm{CH}_{2}\right)\right]_{2}$ (2.5 mol\%), THF (0.1 M), rt, $30 \mathrm{~min}$.

${ }_{30}$ Scheme 6 shows the proposed mechanism explaining the $Z$ selectivity through the less hindered intermedium $\mathbf{1 8}$ in the $\mathrm{Au}(\mathrm{I})$ catalyzed process.

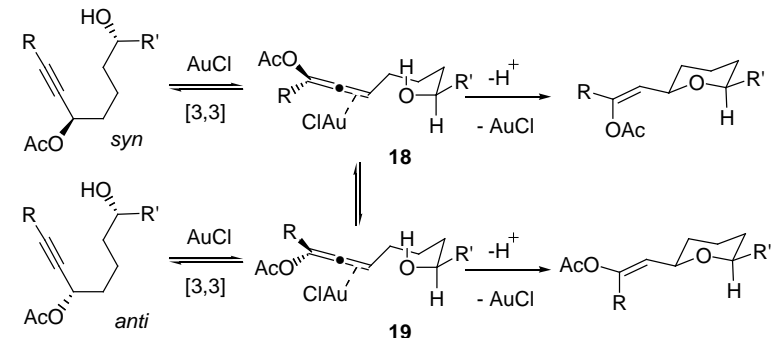

Scheme 6: Cycloetherification mechanism of the gold-catalyzed process.

40

A related mild and efficient approach to the preparation of cyclic ethers bearing an alkyl ketone side chain, in which homopropargylic ethers serve as latent electrophiles through a sequence of alkyne hydration, $\beta$-alkoxy group elimination, 45 and 1,4-addition has been described. ${ }^{17}$ Diastereoselectivity in these transformations can be predicted on the basis of product stability, in accord with studies that products equilibrate under the reaction conditions. $\mathrm{Au}(\mathrm{III})$ and cationic $\mathrm{Au}(\mathrm{I})$ catalysts effectively promote these reactions, 50 with the cationic $\mathrm{Au}(\mathrm{I})$ catalyst showing superior reactivity.

The high activity of gold salts and complexes for the $\mathrm{C}-\mathrm{O}$ bond formation has also been used on enynols for the synthesis of furans. After the first brief example appeared in literature, ${ }^{18}$ Liu et al. developed a general methodology to 55 yield both dihydrofuran and furan skeletons 21 and $23 .^{19}$ Starting from Z-enynols 20 exhibiting a tertiary alcohol group, a wide range of highly substituted dihydrofurans were obtained. Moreover, different gold species and reaction conditions were tested, concluding that the use of 60 extremely small amounts of catalyst $\left(\mathrm{AuCl}_{3} 0.1 \mathrm{~mol} \%\right)$, or even opened air experiments provided the desired compounds with high yields. More interestingly, when moving to secondary alcohols 22 the same versatility was observed for the synthesis of different furan structures 65 (Scheme 7).
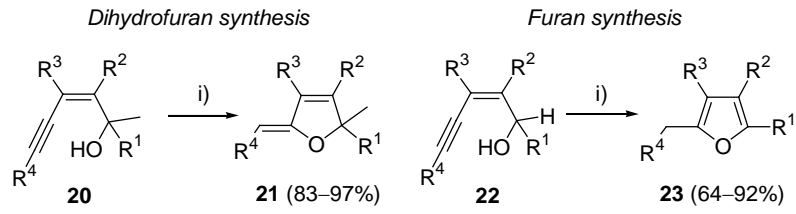

$\mathrm{R}^{1}=0$-ClPh, $\mathrm{Ph}, p$-FPh, 2-thienyl;

$\mathrm{R}^{1}=\mathrm{p}-\mathrm{MePh}, \mathrm{Ph}, \mathrm{p}-\mathrm{MeOPh}, \mathrm{Pr}, \mathrm{p}-\mathrm{FPh} ;$ $\mathrm{R}^{2}=\mathrm{Ph}, \mathrm{C}_{3} \mathrm{H}_{7} ; \mathrm{R}^{3}=\mathrm{Ph}, \mathrm{C}_{3} \mathrm{H}_{7}$; $\mathrm{R}^{2}=\mathrm{Pr}, \mathrm{Bu}, \mathrm{Ph}, \mathrm{Et} ; \mathrm{R}^{3}=\mathrm{Pr}, \mathrm{Bu}, \mathrm{Ph}, \mathrm{Et} ;$ $\mathrm{R}^{4}=\mathrm{Ph}, \mathrm{Cy}, \mathrm{Bu}, \mathrm{p}-\mathrm{MePh}$.

Scheme 7: Synthesis of furans and dihydrofurans from Z-enynols. i) $\mathrm{AuCl}_{3}(1 \mathrm{~mol} \%)$ or $\mathrm{Au}\left(\mathrm{PPh}_{3}\right) \mathrm{Cl} / \mathrm{AgOTf}(1 \mathrm{~mol} \%)$ in DCM, rt, 1-4 h.

70

Every Z-enynol was prepared from commercially available chemicals, by a cross coupling Zr-catalyzed procedure. The authors also reported the addition of $\mathrm{AuCl}_{3}$ to this reaction media, getting the desired final furan systems, with a 75 notable yield decrease (up to $12 \%$ ), but in just one step.

Hashmi et al. have also recently reported another way to afford furan structures from enynols. Various 2-alkynylallyl 
alcohols were synthesized by a generally applicable Sonogashira coupling protocol. Subsequent gold-catalyzed transformations were investigated. The use of $\mathrm{Au}(\mathrm{I})$ catalysts bearing carbene ligands, of either the $\mathrm{N}$ 5 heterocyclic carbene or nitrogen acyclic carbene type, delivered the desired products with low catalyst loadings and under very mild reaction conditions. ${ }^{20} \mathrm{~A}$ broad array of substrates was tested, including alkyl-, alkenyl-, and arylsubstituted alkynes, as well as substrates with two alkynyl 10 moieties. The methodology turned out to have a broad scope. Secondary allyl alcohols were also tolerated, and the resulting trisubstituted furans could be isolated in high yields. The transformation of even bifunctional substrates to the corresponding bisfurans opens interesting aspects for 15 synthetic chemistry.

These results clearly show the benefits of gold catalysis on oxycycloisomerization reactions. Enynol cyclizations have been carried out before in the presence of strong base promotors, ${ }^{21}$ wich was not possible on base-sensitive 20 systems, under Ru-catalysis, ${ }^{22}$ only for terminal alkynes, or by $\mathrm{Pd}$-catalyzed experiments, ${ }^{23}$ were temperatures up to $100^{\circ} \mathrm{C}$ were needed. Thus, compared to previously reported works, Au-mediated processes provide higher versatility, functional group compatibility, and milder conditions.

25 The 3-furanone moiety is also a synthetic target of special interest. ${ }^{24}$ Again, opposite to the traditional preparation procedures wich usually need harsh conditions and provide low yields, ${ }^{25}$ Au-catalyzed methodology emerges as an effective and easy way to obtain this recurring structures. 30 Akai et al. recently developed the gold mediated cyclization of $\gamma$-hydroxyalkynones $\mathbf{2 4}^{26}$ Although they described sucesfull experiments with single catalysts, such as $\left(\mathrm{PPh}_{3}\right) \mathrm{AuNTf}_{2}$ or $\left[\left(\mathrm{PPh}_{3}\right) \mathrm{Au}_{3} \mathrm{O}^{+} \mathrm{BF}_{4}^{-}\right.$, the best results were observed employing $\left(p-\mathrm{CF}_{3} \mathrm{C}_{6} \mathrm{H}_{4}\right)_{3} \mathrm{PAuCl}$ together with 35 AgOTf as additive. Thus, many $3(2 \mathrm{H})$-furanone systems 25 were prepared in good to high yields as it is shown in Scheme 8 .

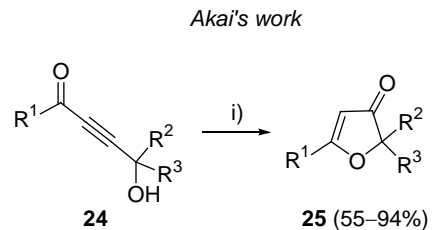

$\mathrm{R}^{1}=\mathrm{Ph}\left(\mathrm{CH}_{2}\right)_{2}$, Me, $t-\mathrm{Bu}, n-\mathrm{C}_{5} \mathrm{H}_{11}, \mathrm{Ph}, \mathrm{PMP}$, $\mathrm{Ph}(\mathrm{CH}=\mathrm{CH}), \mathrm{R}^{2}=\mathrm{Me}, \mathrm{Ph},-\left(\mathrm{CH}_{2}\right)_{4^{-}}, \mathrm{H}$; $\mathrm{R}^{3}=\mathrm{Me},-\left(\mathrm{CH}_{2}\right)_{4^{-}} ; \mathrm{H}$.

Scheme 8: Synthesis of 3-furanones and dihydrofuranones. i) ( $p$ $\left.{ }_{40} \mathrm{CF}_{3} \mathrm{C}_{6} \mathrm{H}_{4}\right)_{3} \mathrm{PAuCl} / \mathrm{AgOTf}$ (5 mol\%), toluene, rt, 1-3.5 h. ii) $\left(\mathrm{PPh}_{3}\right) \mathrm{AuNTf}_{2}$ (5 mol\%), 3,5-dichloropyridine (2 eq.), $\mathrm{MsOH}$ (1.2 eq), DCE, rt, 2.5h.

$\mathrm{R}=\mathrm{CH}_{2} \mathrm{OBn}, \mathrm{C}_{4} \mathrm{H}_{8} \mathrm{Br}, \mathrm{C}_{4} \mathrm{H}_{8} \mathrm{~N}_{3}$, $\mathrm{Ph}, n-\mathrm{C}_{5} \mathrm{H}_{11}$
The only disadvantage derived from this methodoloy is the 45 preparation of the starting materials. Although it is well stated and don't take more than two steps, Zhang and coworkers sorted this inconvenience on related compounds by adding an external oxidant (pyridine $N$-oxides) to the cyclization experiments of readily available alkynols $\mathbf{2 6}$ 50 (Scheme 8). ${ }^{27}$

From the mechanistic point of view, this strategy allowed the synthesis of different dihydrofuran-3-ones through a proposed gold carbene intermedia 29, in front of the $\pi$ activated gold complex $\mathbf{2 8}$ proposed for the $\gamma$ 55 hydroxyalkynone cyclization (Scheme 9).

Even this procedure could be more assimilable to a cascade process than to a single cycloisomerization example, we found it interesting to be included at this stage as a clear comparison between both furanone synthetic methods.
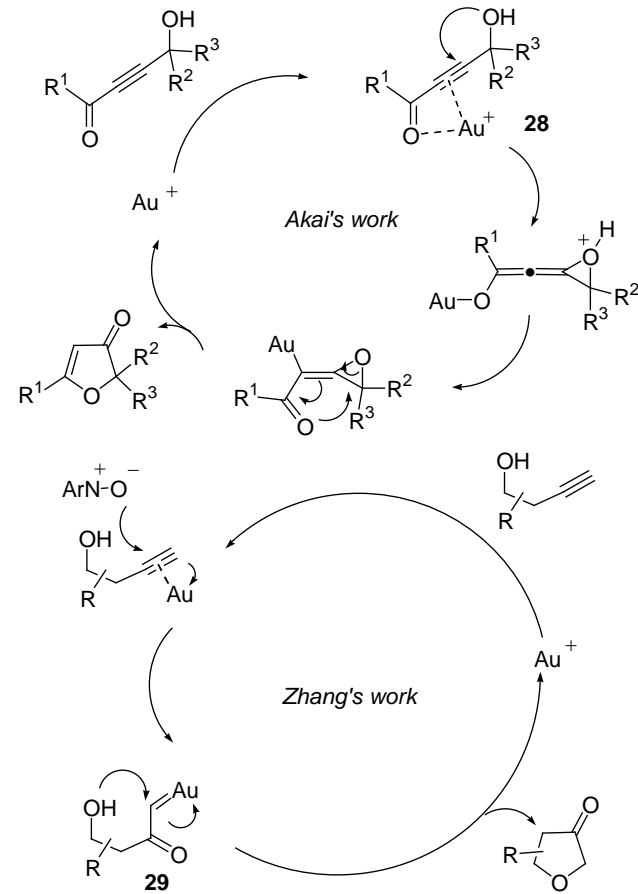

60

Scheme 9: Proposed reaction mechanisms for both $\gamma$ hydroxyalkynone cyclization and gold-carbene mediated alkynol oxidation/cycloisomerization cascade. $\mathrm{C}_{2} \mathrm{H}_{4} \mathrm{Ph}, \mathrm{C}_{3} \mathrm{H}_{6} \mathrm{OMOM}, \mathrm{Cy}, \mathrm{PMP}$,

65 The scope of both processes was extended. In one hand, some examples for the synthesis of pyranones $\mathbf{3 1}$ by enlarging the hydroxylic chain have been reported. ${ }^{25}$ On the other hand, Zhang et al. studied the use of the cascade methodology for the synthesis of the more ring strained 70 oxetan-3-ones 33 (Scheme 10). ${ }^{28}$ 


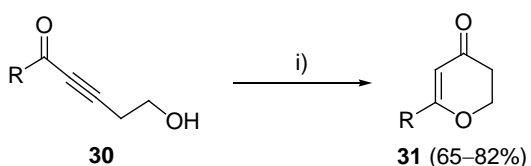

$\mathrm{R}=\mathrm{Ph}, \mathrm{Ph}\left(\mathrm{CH}_{2}\right)_{2}$<smiles>[R]C#CC([R])([R])O</smiles>

32

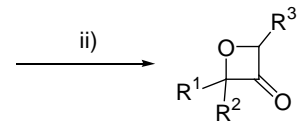

$33(57-83 \%)$
$\mathrm{R}^{1}=\mathrm{Cy}, \mathrm{Ph}, \mathrm{Me}, \mathrm{Ph}\left(\mathrm{CH}_{2}\right)_{2},-\left(\mathrm{CH}_{2}\right)_{4^{-}},-\left(\mathrm{CH}_{2}\right)_{5},-\left(\mathrm{CH}_{2}\right)_{6}$;

$\mathrm{R}^{2}=\mathrm{H}, \mathrm{Me}, \mathrm{Pr}, i-\mathrm{Pr},-\left(\mathrm{CH}_{2}\right)_{4^{-}},-\left(\mathrm{CH}_{2}\right)_{5},-\left(\mathrm{CH}_{2}\right)_{6} ; \mathrm{R}^{3}=\mathrm{H}, \mathrm{CO}_{2} \mathrm{Et}$.

Scheme 10: Gold-catalyzed pyranone and oxetan-3-one syntheses. i) $\left(p-\mathrm{CF}_{3} \mathrm{C}_{6} \mathrm{H}_{4}\right)_{3} \mathrm{PAuCl} / \mathrm{AgOTf}(5 \% \mathrm{~mol})$, toluene, rt, 1-3.5 h. ii) (2Biphenyl)Cy $\mathrm{AuNTf}_{2}$ or ${ }^{i} \mathrm{PrAuNTf}_{2}$ (5 mol\%), 3,5-dichloropyridine 5 (2 eq.), $\mathrm{Tf}_{2} \mathrm{NH}$ (1.2 eq), DCE, rt, 2.5h.

\subsection{Cascade processes involving gold-catalyzed oxycyclization}

${ }_{10}$ Cascade processes represent a usefull access to complex organic strutures from quite simple reactants. ${ }^{29}$ Due to the ability of gold species to catalyze unusual reactions, many examples have appeard incorporing gold-mediated strategies for the synthesis of different heterocyclic systems. ${ }_{15}$ Concretely, Au-oxycyclization tandem reactions are present in many recent reports. ${ }^{30}$

Tandem cycloisomerization/hydroalkoxylation of homopropargylic alcohols is one of the most simple and efficient examples. This methodology leads to 20 tetrahydrofuranyl ethers, important building blocks and naturally occurring skeletons with diverse biological activities. ${ }^{31}$ Krause et al. reported a methodology consisting of a dual catalyst system, including a gold complex for the first cyclization and a Brönsted acid for the 25 hydroalkoxylation step (Scheme 11). ${ }^{32}$ Thus, the family of tetrahydrofuranyl ethers $\mathbf{3 4}$ was obtained.

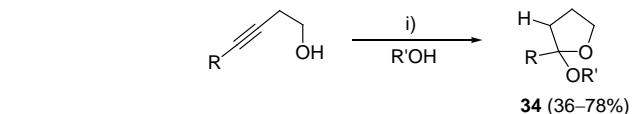

$\mathrm{R}=0-\mathrm{BrPh}, \mathrm{PMP}, p-\mathrm{MePh}, p-\mathrm{MeO}_{2} \mathrm{CPh}, \mathrm{Ph} ; \mathrm{R}^{\prime}=\mathrm{Me}, \mathrm{Et},{ }^{i} \mathrm{Pr},{ }^{\mathrm{t}} \mathrm{Bu}, \mathrm{MeO}\left(\mathrm{CH}_{2}\right)_{2}$.

Reaction Mechanism

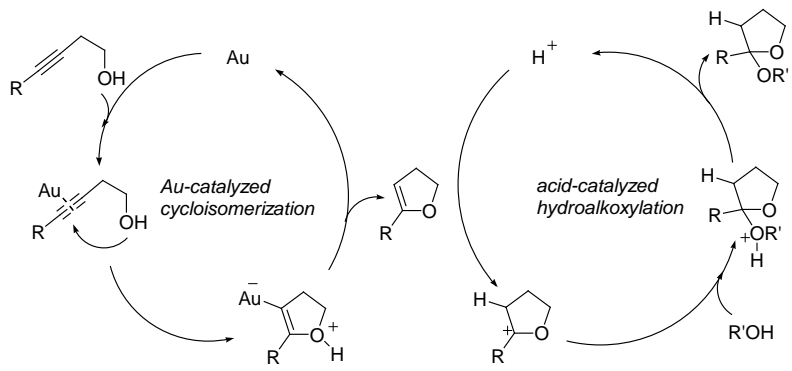

30 Scheme 11: Tandem cycloisomerization/hydroxyalkoxylation and reaction mechanism. i) $\mathrm{Ph}_{3} \mathrm{PAuCl}_{\mathrm{AgBF}}$ (2 mol\%), $p$-TsOH (10 mol\%), R'OH (normally as solvent), rt, 45 min-3h.

A similar idea was recently applied on $\beta$-lactam structures 3535 and $38 .^{33}$ It was found that the use of gold catalysis selectively led to a tandem cycloisomerization/ hydroxylation, affording structures $\mathbf{3 6}$ and 39, while the use of silver-based systems yielded the corresponding exo-dig cycloadducts $\mathbf{3 7}$ and $\mathbf{4 0}$ respectively (Scheme 12). Thus, 40 gold catalysis provides an easy route for tetrahydrofuranand pyran-based $\beta$-lactams, structures of interest but with relatively few methods of obtention. ${ }^{34}$

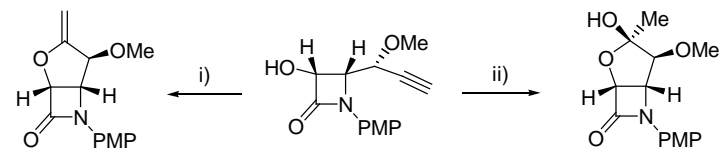

5-exo-cyclization

$37(60 \%)$

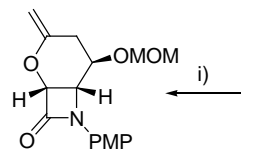

6-exo-cyclization

$40(69 \%)$

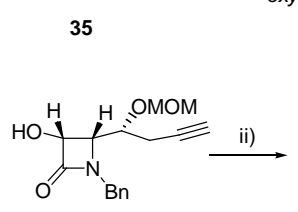

xycyclization/hydroxylation 36 (59\%)

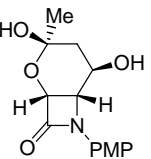

oxycyclization/hydroxylation

Scheme 12: Tandem $\mathrm{Au}$-catalyzed cycloisomerization/ 45 hydroxylation vs Ag-promoted cycloisomerization on $\beta$-lactam alkynols. i) $\mathrm{AgOAc}, \mathrm{Et}_{3} \mathrm{~N}$, acetone, rt., 96h. ii) $\mathrm{AuCl}_{3}$ (5 mol\%), PTSA (10 mol\%), DCM, rt., 6h.

Patil and coworkers have deeply studied the 50 cycloisomerization based tandem reactions of alkynols. Looking through many of their recent works we can find several examples of interest. One of them stablished the first double hydroamination of alkynes. ${ }^{35}$ Starting from 2aminobenzamides $\mathbf{4 2}$ and different alkynols, a gold55 catalyzed formal Markovnikov process was reported (Scheme 13). $\mathrm{PtBr}_{4}$ was also tested as catalyst for this procedure, finding similar results as the ones for gold. 

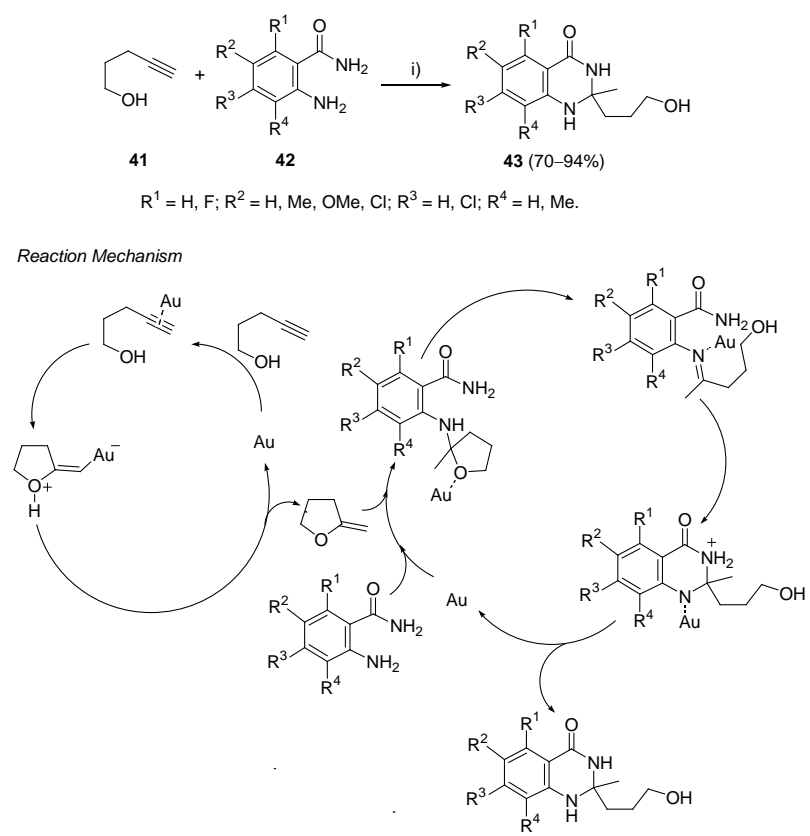

Scheme 13: Double hydroamination of alkynols catalyzed by gold and reaction mechanism. i) Alkynol: 2-aminobenzamide (1:1), $\mathrm{Au}\left(\mathrm{PPh}_{3}\right) \mathrm{Cl}(5 \mathrm{~mol} \%), \mathrm{MeOH}, 80^{\circ} \mathrm{C}, 12-30 \mathrm{~h}$.

5

Two related examples of cascade gold-mediated cycloisomerizations have been reported. ${ }^{36}$ In both of them the extremely high activity of gold complexes is used to catalyze the methylene tetrahydrofuran formation from 10 alkynols $\mathbf{4 4}$ and $\mathbf{4 7}$, the indol synthesis from 2propargylanilines $\mathbf{4 5}$ or phenylhydrazines $\mathbf{4 8}$, and even the coupling reaction between both species in the first case. Thus, an interesting family of substituted indoles 46 and 49 was easily accesible through a one pot gold-mediated 15 procedure. Moreover, several catalysts were tested, finding the best results for the pair $\mathrm{Ph}_{3} \mathrm{PAuCl} / \mathrm{AgOTf}$ (Scheme 14).

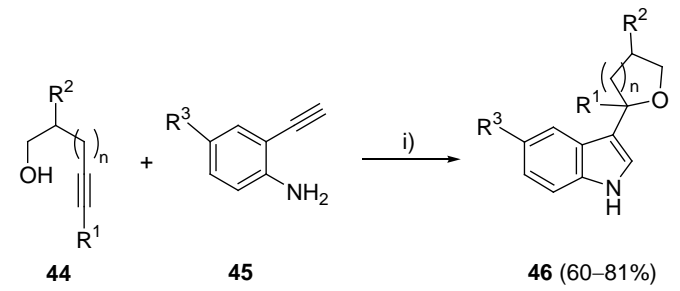

$\mathrm{n}=1,2 ; \mathrm{R}^{1}=\mathrm{H}, \mathrm{Me}, \mathrm{Et}, \mathrm{n}-\mathrm{Hex}, \mathrm{p}-\mathrm{MeC}_{6} \mathrm{H}_{4} ; \mathrm{R}^{2}=\mathrm{H},-\left(\mathrm{CH}_{2}\right)_{5}^{-},-\left(\mathrm{CH}_{2}\right)_{4^{-}}, \mathrm{Ph}$; $\mathrm{R}^{3}=\mathrm{NO}_{2}, \mathrm{Cl}, \mathrm{Me}, \mathrm{H}, \mathrm{CN}, \mathrm{CO}_{2} \mathrm{Me}, \mathrm{F}, \mathrm{CF}_{3}, \mathrm{CH}_{2} \mathrm{CN}$.

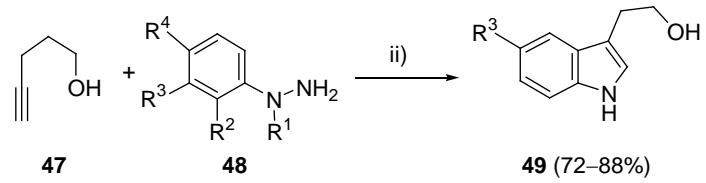

$\mathrm{R}^{1}=\mathrm{H}, \mathrm{Me}, \mathrm{Cbz}$, Allyl, Bn, Boc; $\mathrm{R}^{2}=\mathrm{H}, \mathrm{I} ; \mathrm{R}^{3}=\mathrm{H}, \mathrm{OMe}, \mathrm{R}^{3}=\mathrm{R}^{2}=-\left(\mathrm{CH}_{2}\right)_{4^{-}}$; $\mathrm{R}^{4}=\mathrm{H}, \mathrm{Me}, \mathrm{Cl}, \mathrm{Br}, \mathrm{F}$.

Scheme 14: One pot synthesis of substituted indoles. i)
Propargylanilines/alkynol (1:1.1), $\mathrm{Ph}_{3} \mathrm{PAuCl} / \mathrm{AgOTf}$ (5 mol\%), 20 DCE, $\quad 60^{\circ} \mathrm{C}, \quad 12-18 \mathrm{~h} . \quad$ ii) Phenylhydrazine/alkynol (1:1.2), $\mathrm{Ph}_{3} \mathrm{PAuNTf}_{2}$ (2 mol\%), pTSA (1 eq), toluene, $100^{\circ} \mathrm{C}$, $2 \mathrm{~h}$.

Barluenga et al. has employed the gold-catalyzed oxycyclization in enynols, to develop a cascade 25 cycloisomerization/Diels-Alder reaction. ${ }^{37}$ Starting from different enynols 50, an interesting selectivity was observed. When homopropargylic alcohols were employed, the first step went specifically through a endocycloisomerization pathway, finally yielding fused 30 heterocyclic systems $\mathbf{5 1}$. On the other hand, when the alcohol chain was enlarged, the process underwent through an exo-cycloisomerization pathway, consequently yielding spiranic systems $\mathbf{5 2}$ as the only final products (Scheme 15). A double use of the gold catalyst was encountered, as much 35 as the Diels-Alder step was observed to occur much more slower and only at higher temperatures in the absence of the metal salt. Moreover, among many other catalyst reported in this work, such as $\mathrm{Pt}$ or Ir species, $\mathrm{AuCl}_{3}$ provided the best conversion, and the easiest handling.

40

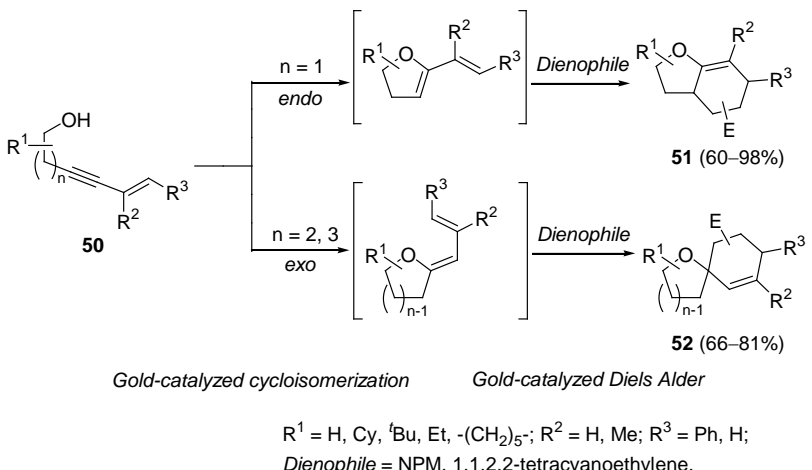

Scheme 15: Cascade cycloisomerization/Diels-Alder of enynols. Reaction conditions: $\mathrm{AuCl}_{3}$ (3 mol\%), DCM, rt for $\mathrm{n}=1$ or DCE, reflux for $n=2,3$.

45 According to the results summarized above, there is therefore a promising rising number of applications starting from methylene tetrahydrofuran $\mathbf{5 3}$ as a formal building block. Thus, as it is shown on Scheme 16, tetrahydrofuranyl ethers, substituted indoles, different fused- and spiro50 oxacyclic systems and hydroaminated alkynes could be achieved from quite simple alkynols, in a single step.

55 


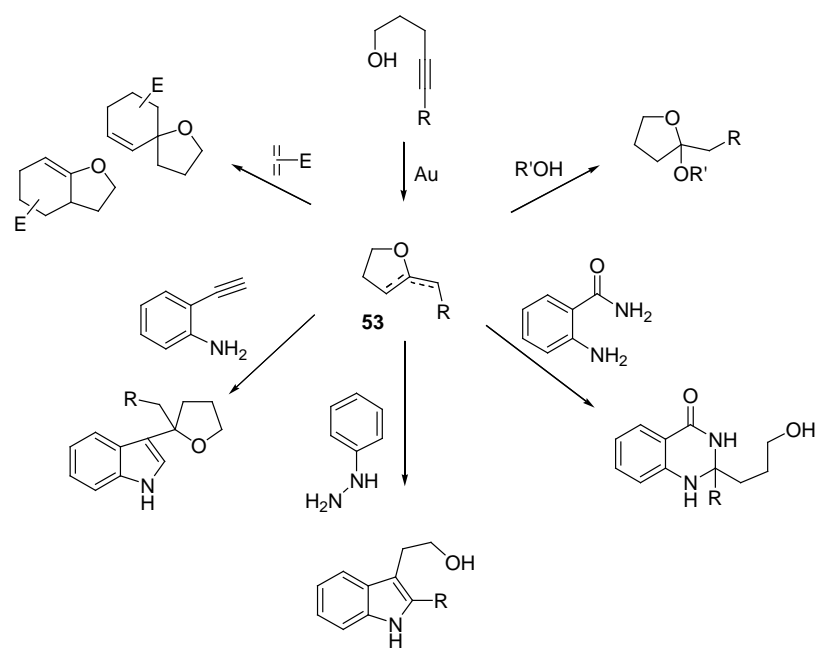

Scheme 16: Methylene tetrahydrofuran as building block in goldcatalyzed reactions of alkynols.

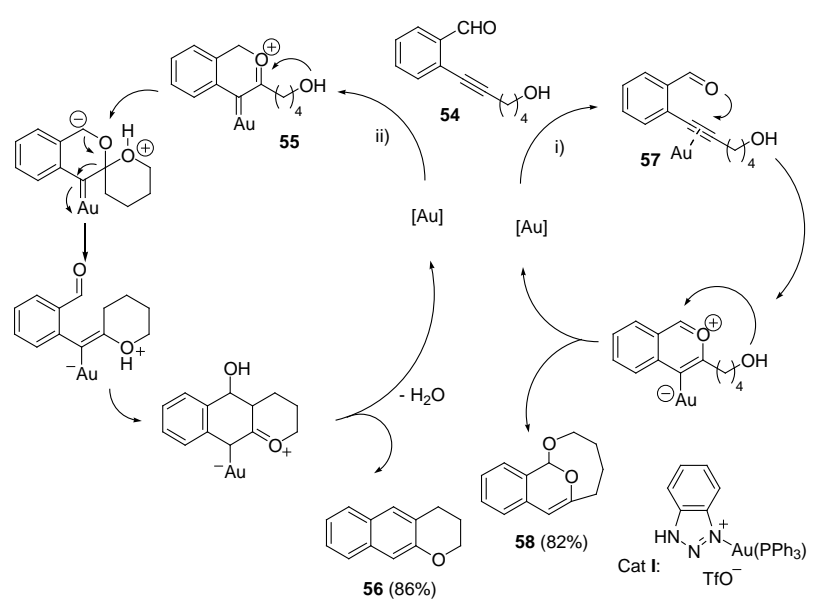

Scheme 17: Gold catalyzed cascade annulations of 2-(ynol)aryl aldehydes. i) Cat I (5 mol \%), DCM, rt, 12h. ii) $\mathrm{AuCl}_{3}$ (5 mol \%), DCM, rt, $12 \mathrm{~h}$.

10 Different cascade processes, which do not involve the most common methylene tetrahydrofuran intermedia, have also been reported. In one of them, Hammond and coworkers recently proved the versatility of the gold catalysis promoting unexpected reactions. ${ }^{38}$ They found that the use 15 of two different gold salts interestingly changed the course of 2-(ynol)aryl aldehyde 54 oxycyclization reactions. Thus, $\mathrm{AuCl}_{3}$ favored the formation of the carbene intermedia $\mathbf{5 5}$ which yielded benzochromane $\mathbf{5 6}$, while the use of a goldtriazol catalyst allowed the synthesis of benzobicycloacetal 2058 , through a gold-alkyne $\pi$-complex 57. Both structures were obtained with high yields, setting a facile synthetic route to complex heterocyclic systems (Scheme 17).

A different cascade process has been reported, starting in this case from enynols, and yielding different types of 25 heterobicycles, as bridged, spiranic or fused compounds, 60, 62 or 64, respectively. ${ }^{39}$ A detailed study of different catalysts, mechanistic considerations, and several starting substrates was carried out (Scheme 18).

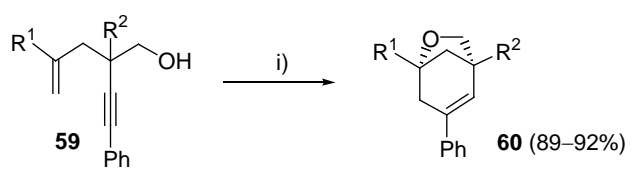

$\mathrm{R}^{1}=\mathrm{Ph}, \mathrm{Me}: \mathrm{R}^{2}=\mathrm{Me}, \mathrm{H}, 3,5$-dimethoxyphenyl.
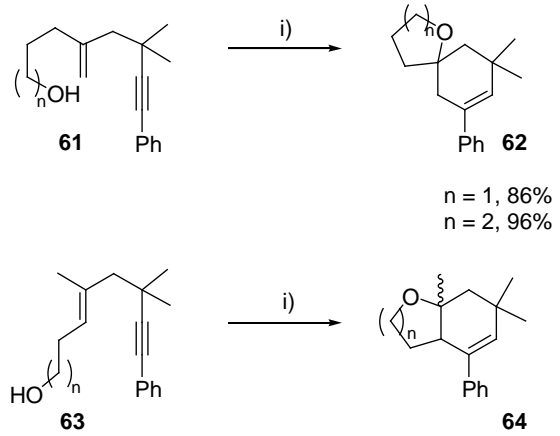

$\mathrm{n}=1,90 \%$ (trans diastereomer) $\mathrm{n}=2,90 \%$ (cis diastereomer)

30

Scheme 18: Gold catalyzed formation of heterobicyclic systems. i) $\mathrm{AuCl}_{3}$ or $\left[\mathrm{Au}\left(\mathrm{PPh}_{3}\right)\right] \mathrm{ClO}_{4}(5 \mathrm{~mol} \%), \mathrm{DCM}$ or MeCN, rt, $1 \mathrm{~h}$.

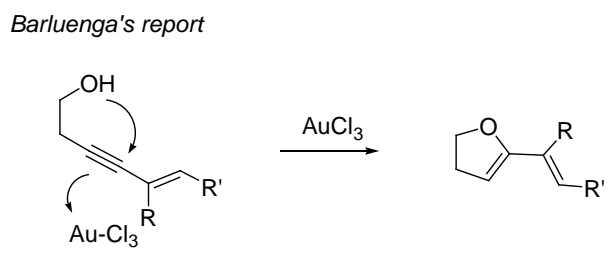

Zhang's report

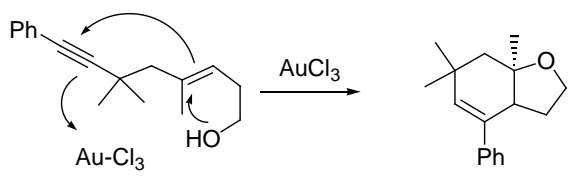

66

Scheme 19: Enynol reactivity divergency under $\mathrm{AuCl}_{3}$ catalyzed 35 cycloisomerization processes.

Compared to Barluenga's previously commented work (Scheme 15), we can set how a slightly difference on the enynol structure changes dramatically the course of the 40 reaction. Using the same reaction conditions (3-5 mol\% of $\mathrm{AuCl}_{3}, \mathrm{DCM}$ ), the nucleophilic hydroxy group starts the process by attacking the alkene or the gold-activated alkyne, depending on the structural conformation of the starting materials $\mathbf{6 5}$ and $\mathbf{6 6}$. Thus, both studies represent a proof of 45 alkynol versatility and open a door to learn more of its unexpected behaviour (Scheme 19).

\section{Gold-catalyzed oxycyclization in alkynediols}

Alkynediols have also been tested in gold-catalyzed 
cycloisomerization reactions. Despite their reactivity follows the same pattern as the one observed for alkynols, it is in the final compounds where we find the main interest. This fact has encouraged us to dedicate special attention to 5 some of the recent papers dealing with this item.

Highly substituted furans have been accesible from easily prepared enyne-1,6-diols through a selective gold-catalyzed cyclization of alkynediols 67. ${ }^{40}$ Many catalysts were tested, finding with $\mathrm{Au}$-based salts and complexes the best results, 10 while another transition metals like Ag failed. The scope of different substituents was also studied, and in every case the authors observed a complete selectivity for the furan structures 68, resulting from the attack of the activated hydroxy group, while the second one stayed inert. This 15 regioselectivity appears as the main interest of the work. Two additional experiments on $O$-protected substrates 69 demonstrated that cyclization from $\mathrm{OH}$ at $\mathrm{C} 6$ position is not accesible (Scheme 20).

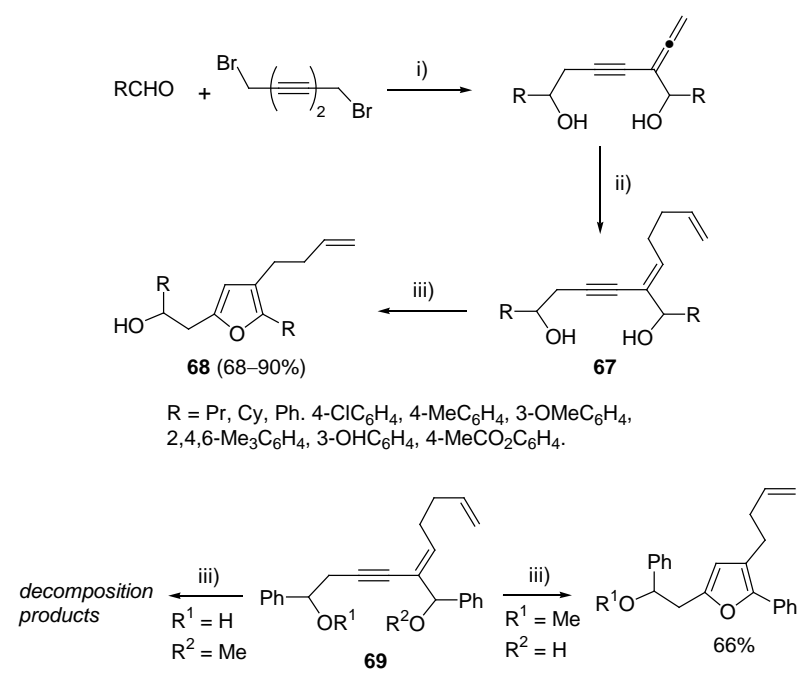

20

Scheme 20: Synthesis of furans from enyne-1,6-diols. i) In, LiI, THF, rt. ii) In, allyl bromide, THF, rt iii) $\mathrm{Ph}_{3} \mathrm{PAuCl} / \mathrm{AgOTf}(5$ mol\%), DCM, rt, 5-10 min.

${ }_{25}$ Ma et al. recently reported another example using enyne1,6-diols to afford substituted furans. ${ }^{41}$ In this case, the elimination of $\mathrm{H}_{2} \mathrm{O}$ from the cyclic product became the promotor of the ring aromatization, opposite to previous related works, where the furan ring is created by double 30 bond isomerization. Many substituents were tested, and among several catalysts, gold ones appeared as the most convenient. While different palladium complexes or silver salts afforded furan structures $\mathbf{7 1}$ with only 15\% yield in the best cases, $\mathrm{PPh}_{3} \mathrm{AuCl}$ provided more than $80 \%$ conversion 35 employing much more milder reaction conditions (Scheme 21).

More interestingly, some reports have appeared describing the simultaneous nucleophilic attack of both hydroxylic groups to gold-activated alkynes. Thus, starting from 40 alkynediols, an easy route to complex structures such as bicyclic ketals, spiroketals or even cage-like strutures was accesible.

Genet et al. pioneered a bicyclic ketal synthesis through gold catalyzed alkynediol cycloisomerization. ${ }^{42}$ An 45 interesting family of strained ketals 73, present in many natural structures, ${ }^{43}$ was therefore accesible by using both $\mathrm{AuCl}$ and $\mathrm{AuCl}_{3}$ in excellent yields. Moreover, the process was compatible with different functional groups, and no traces of methanol addition was observed when the reaction 50 took place in this solvent (Scheme 22).

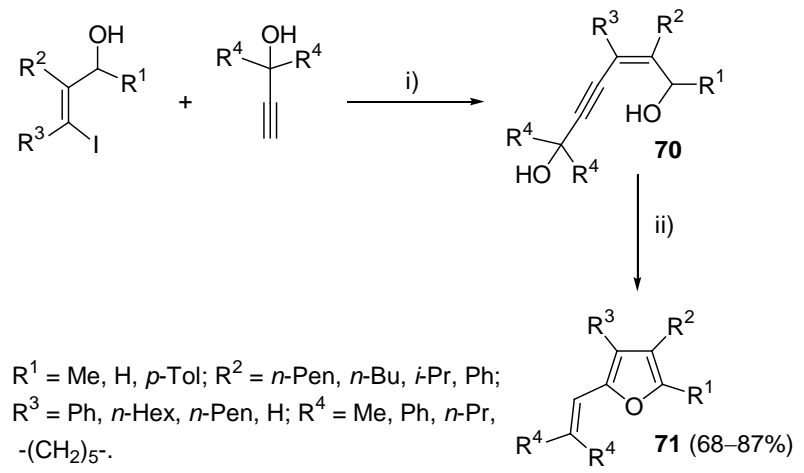

Scheme 21: Synthesis of furans from enyne-1,6-diols. i) Alkene/alkyne (1:2), CuI (2 mol\%), $\mathrm{Pd}\left(\mathrm{PPh}_{3}\right)_{2} \mathrm{Cl}_{2}$ (3 mol\%), DMSO, $\mathrm{Et}_{3} \mathrm{~N}$. ii) $\mathrm{Au}\left(\mathrm{PPh}_{3}\right) \mathrm{Cl} / \mathrm{AgOTf}$ (2 mol\%), DCM, rt, $2 \mathrm{~h}$.

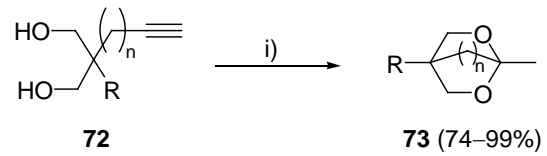

$\mathrm{R}=\mathrm{Bn}, \mathrm{Ph}, n-\mathrm{Bu}$, cinnamyl, allyl, cyclohex-2-enyl, 3-methylbut-2-enyl; $\mathrm{n}=1,2$.

Scheme 22: Synthesis of strained bicyclic ketals. i) $\mathrm{AuCl}$ or $\mathrm{AuCl}_{3}$, (2 mol\%), $\mathrm{MeOH}, \mathrm{rt}, 30-50 \mathrm{~min}$.

Starting from alkyne-1,5-diols $\mathbf{7 4}$, it was found that together 60 with the expected ketals 75, traces of substituted tetrahydropyran systems 76 came out, ${ }^{44}$ specially when the reaction time was prolonged, or the catalyst loading increased. After going through numerous reaction conditions, the process was optimized, founding that gold 65 salts promoted both transformations, while another metal catalysts or Brönsted acids failed (Scheme 23).

It was found an unusual gold complex that increased the selectivity on oxycyclization of unactivated internal alkynes. After an exhaustive screening of catalysts, it was 70 observed that $\left[\mathrm{Cl}_{2} \mathrm{Pt}\left(\mathrm{CH}_{2}=\mathrm{CH}_{2}\right)\right]_{2}$ or $\mathrm{PtCl}_{2}$ improved the 6exo/7-endo selectivity up to $116: 1$ on system $77 . .^{45}$ Nevertheless, when it was studied the 5-exo/6-endo selectivity on 4-alkynols $\mathbf{8 0}$, results were more dissapointing. Only when the reaction took place under ${ }_{75} \mathrm{MeAuPPh}_{3} / \mathrm{AgPF}_{6}$ as catalyst the selectivity for the exo struture rised to $6.6: 1$. On the other hand, depending on the $O$-protecting group in use, ketal systems 82 were also obtained (Scheme 24). 


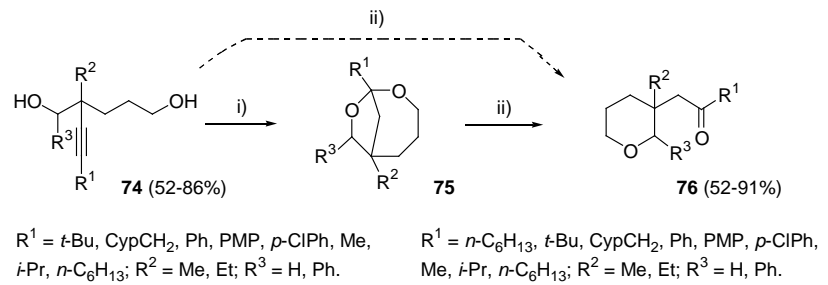

Reaction mechanism for the ketal-tetrahydropyran interconversion

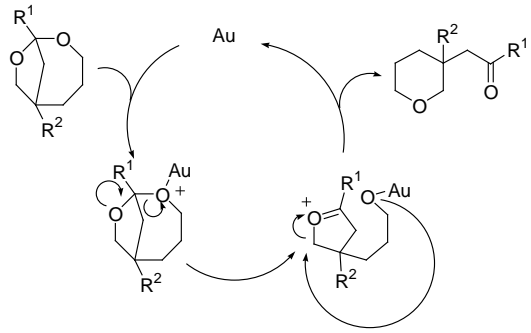

Scheme 23: Synthesis of bicyclic ketals and tetrahydropyrans from alkyne-1,5-diols. i) AuCl (2 mol\%), DCM, rt, 2-10 min. ii) AuCl (6 $\mathrm{mol} \%$ ), DCM (5 mL/mmol), rt, 6-24h.

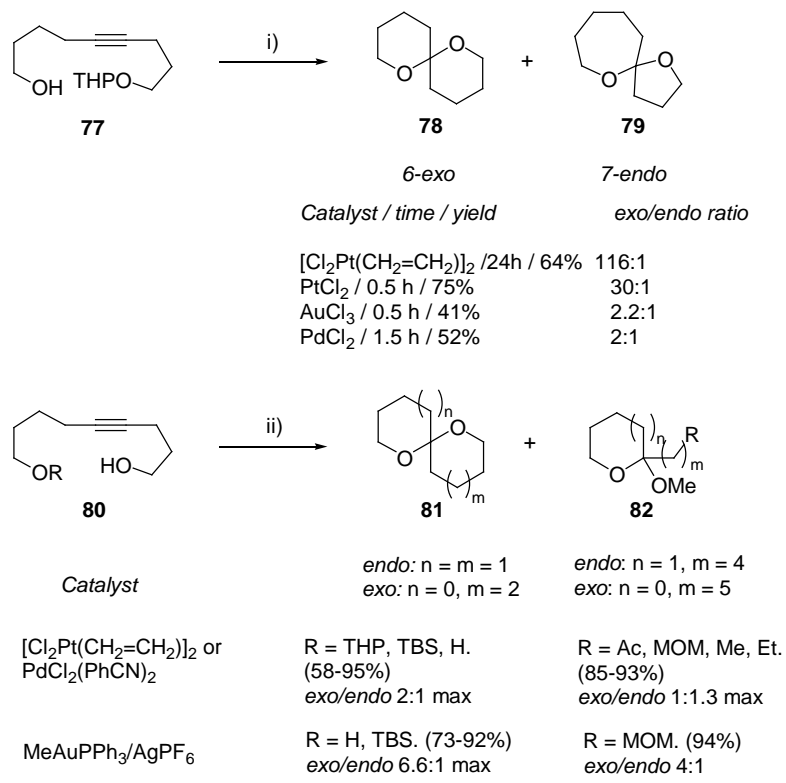

Scheme 24: Ketal synthesis using gold catalyzed oxycyclization of alkynediols. i) cat (1-5 mol\%), $\mathrm{Et}_{2} \mathrm{O}, \mathrm{rt}, 0.5-1 \mathrm{~h}$. ii) cat (1-5 mol\%), $\mathrm{Et}_{2} \mathrm{O}, \mathrm{PPTS}, \mathrm{HC}(\mathrm{OMe})_{3}$, rt, 3-13h.

A new mode of reactivity of propargyl alcohols has been reported that enables a facile preparation of substituted 5and 6-membered ring spiroketals from propargylic triols by action of the cationic gold(I) complex generated from ${ }_{15} \mathrm{Au}\left[\mathrm{P}(t-\mathrm{Bu})_{2}(o\right.$-biphenyl $\left.)\right] \mathrm{Cl}$ and AgOTf. The reactions are rapid and generally high yielding, providing a concise synthesis of useful building blocks in short order. ${ }^{46}$

Starting from bis(homopropargylic) diols 83, interesting tricyclic cage-like systems $\mathbf{8 4}$ were obtained. ${ }^{47}$ For that 20 purpose, different diyne-diols composed of two terminal homopropargylic alcohol groups were tested, in the presence of an external nucleophile such as water or aromatic amines. Gold and platinum catalysts were employed, yielding the desired structures in reasonable 25 yields. Thus, a multistep process consisting on a selective hydroalcoxylation and hydration or hydroamination allowed the formation of eight new bonds in one single reaction step (Scheme 25).

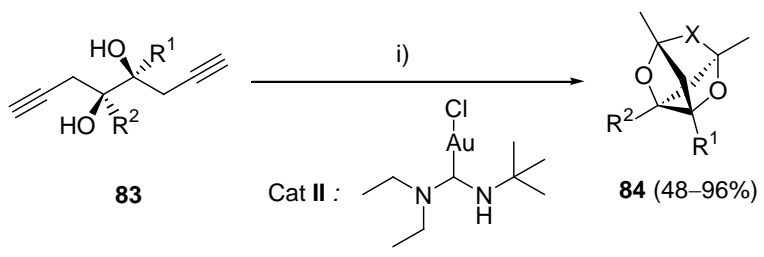

$\mathrm{X}=\mathrm{O}, \mathrm{N}-\mathrm{Ar} ; \mathrm{R}^{1}, \mathrm{R}^{2}=\mathrm{Ph}, 4-\mathrm{BrPh}, 4-\mathrm{OMePh}, \mathrm{Me}$

30 Scheme 25: Cage-like structure synthesis from diyne-diols. i) Cat. II (2 mol\%), $\operatorname{AgNTf}_{2}$ (2 mol\%), DCM sat. with $\mathrm{H}_{2} \mathrm{O}$, rt, 16h for X $=\mathrm{O} ; \mathrm{CH}_{3} \mathrm{CN}, \mathrm{ArNH}_{2}$ (3 eq.), rt, 16h-6d for $\mathrm{X}=\mathrm{N}-\mathrm{Ar}$.

The intramolecular cyclizations of 3-alkyne-1,2-diols and 135 amino-3-alkyn-2-ols with a low catalyst loading ( $\theta .0 .5$ mol \%) of the combination of $\left(\mathrm{Ph}_{3} \mathrm{P}\right) \mathrm{AuCl}$ with either $\mathrm{AgNTf}_{2}$ or AgOTf proceeded at room temperature to provide a variety of substituted furans and pyrroles in excellent yields (8598\% yields) ${ }^{48}$ involving coordination 40 of the acetylene bond to a cationic Au species, 5-endo cyclization of the homopropargylic hydroxyl or amino group, and dehydration.

A method for the construction of the bisbenzannelated 5,6spiroketal core of rubromycins starting from alkyndiphenols 45 has been developed, which allows for the synthesis of various substituted 5,6-aromatic spiroketal skeletons under the catalysis of gold reagents. ${ }^{49}$

\section{Gold-catalyzed oxycyclization in total synthesis}

50 The extremely high versatility of gold catalyzed oxycyclization of alkynols was proved by its use in total synthesis. For this reason, it appears interesting to us to collect some examples where the gold-catalyzed rearrangement appears as one of the key steps of the 55 synthetic route.

It has been recently reported the synthesis of aurone skeletons, natural flavonoids, ${ }^{50}$ by an easy three step sequence. Aurones exhibite many interesting biological activities, ${ }^{51}$ and its importance had led to several groups to 60 develop convenient synthetic routes. ${ }^{52}$ Among them, goldcatalyzed oxycyclization provided the best results, as milder reaction conditions and excellent selectivities, avoiding the formation of flavones as byproducts, were achieved (Scheme 26). ${ }^{53}$ Moreover, the present methodology was 65 used for the structural revision of two natural products, such as (Z)-4'-chloroaurone $\mathbf{8 7},{ }^{54}$ and $(Z)-2$ '-hydroxyaurone $\mathbf{8 9},{ }^{55}$ proving that the assumed structure was not the correct one. Thus, flavonoid systems $\mathbf{8 7}$ and $\mathbf{8 9}$ could be prepared by the 
above three step strategy, finding that their spectral data did not match with the natural isolated ones, previously reported. Therefore, the isocumarine $\mathbf{8 8}$ and the flavone $\mathbf{9 0}$ were prepared as the real structures for these natural 5 products (Scheme 26 ).

Trost et al recently completed the total synthesis of bryostatin $16,{ }^{56,57}$ a structurally complex macrolide which exhibits a wide range of biological activities. ${ }^{58}$ Along the proposed 26 step sequence (in the longest linear way, and 1039 steps as the total), the gold-catalyzed 6-endo-dig oxycyclization of alkynol $\mathbf{9 1}$ to generate the inner dihydropyran cycle B in macrocyclic precursor 92 in 65\% yield deserves special mention (Scheme 27).

Okadaic acid 94 is a complex natural structure isolated from 15 marine sponges. ${ }^{59}$ Its biological activities, ${ }^{60}$ together with its attractive chemical structure have focused much interest among the organic chemists. In particular, the presence of several spiroketal motifs in this structure makes it a real challenge from the retrosynthetical point of view. Forsyth 20 and coworkers have reported an efficient synthesis of the C15-C38 fragment, based on the high activity and selectivity of $\mathrm{AuCl}$ for the synthesis of spiroketals $\mathbf{9 8}$ and 100, starting from alkynediols 97 and 99 respectively. ${ }^{61}$ (Scheme 28).

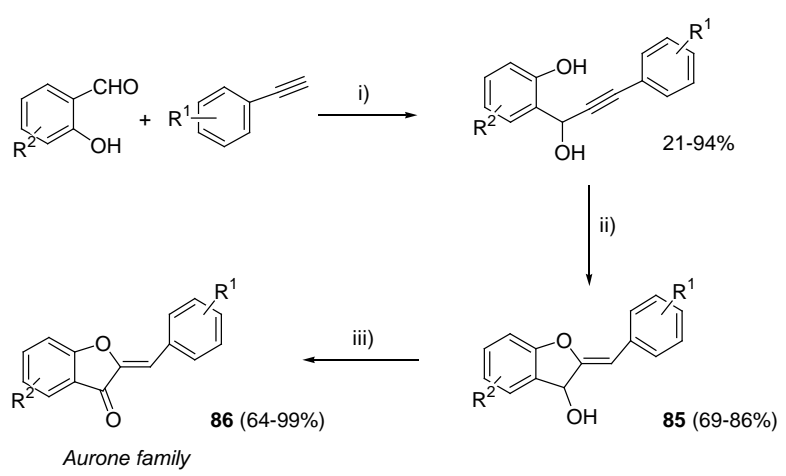

$\mathrm{R}^{1}=\mathrm{H}, 4-\mathrm{Cl}$, 4-OMe, 2-OMe, 3,4-di(OMe); $\mathrm{R}^{2}=\mathrm{H}, 4-\mathrm{NO}_{2}, 4-\mathrm{Br}, 2,5-\mathrm{di}(\mathrm{OMe})$.

Structural revision
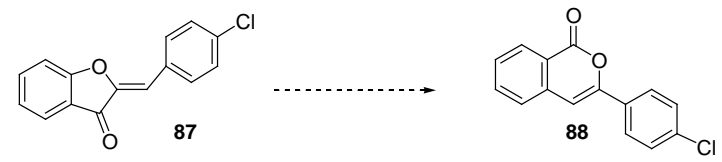

(Z)-4'-Chloroaurone<smiles>O=C1/C(=C/c2ccccc2O)Oc2ccccc21</smiles>

(Z)-2'-Hydroxyaurone
Revised structure 3-(4'-Chloroisocoumarin)

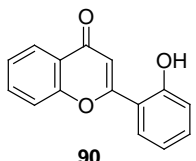

Revised structure 2'-Hydroxyflavone<smiles>C=CCC(=O)C(C)(C)[C@H](CC1CC([OH2+])CC(=O)O1)O[Mg]</smiles><smiles>COC(=O)C#CC[C@@H](O)CC1OC(C)(C)OC1C</smiles>

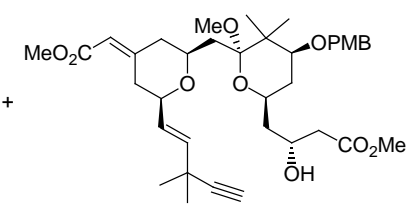

i)

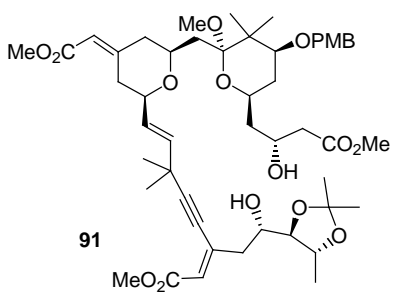

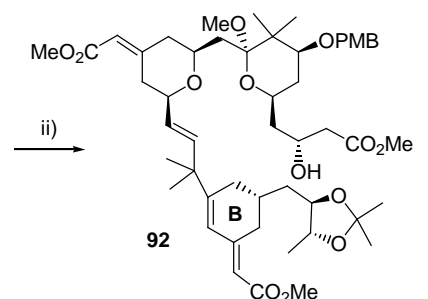

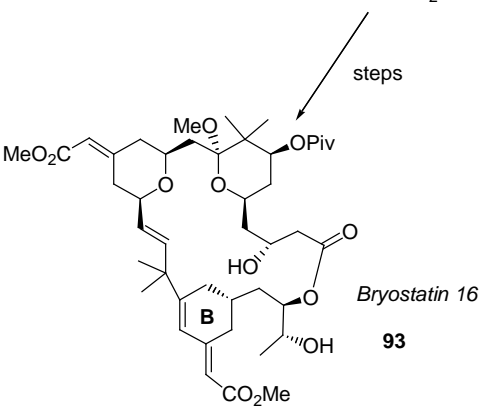

Scheme 27: Total synthesis of bryostatin 16. i) $\mathrm{Pd}(\mathrm{OAc})_{2}(10$ mol\%), TDMPP (10 mol\%), benzene, rt. ii) $\mathrm{AuCl}\left(\mathrm{PPh}_{3}\right)$ (10 mol\%), $\mathrm{AgSbF}_{6}$ (10 mol\%), DCM/MeCN (4:1), $\mathrm{NaHCO}_{3}, 0^{\circ} \mathrm{C}$ to rt.

Scheme 26: Aurone synthesis and structural revision. i) $n$-BuLi (1 eq), $\mathrm{THF},-78^{\circ} \mathrm{C}$ to $-40^{\circ} \mathrm{C}$, 4h. ii) $\mathrm{AuCl}(10 \mathrm{~mol} \%), \mathrm{K}_{2} \mathrm{CO}_{3}(10$ mol\%), MeCN, rt, 30h. iii) $\mathrm{MnO}_{2}$ (10 eq), DCM, rt, 1 h. 

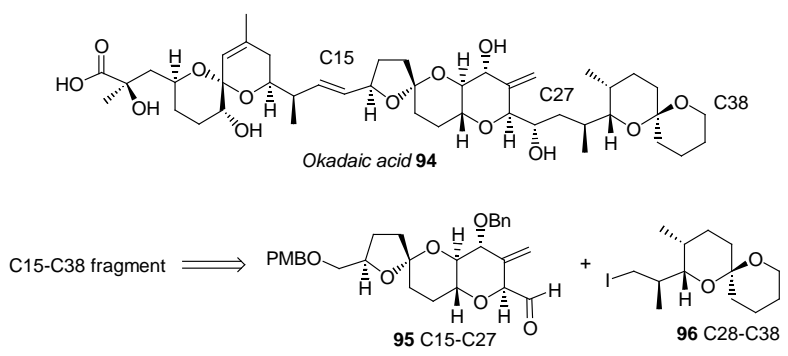

C15-C27 route

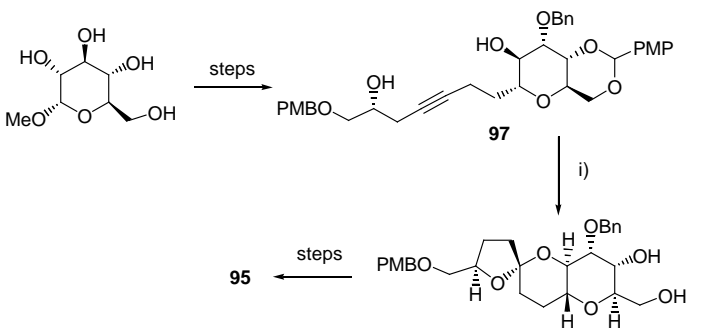

$98(81 \%)$

C28-C38 route

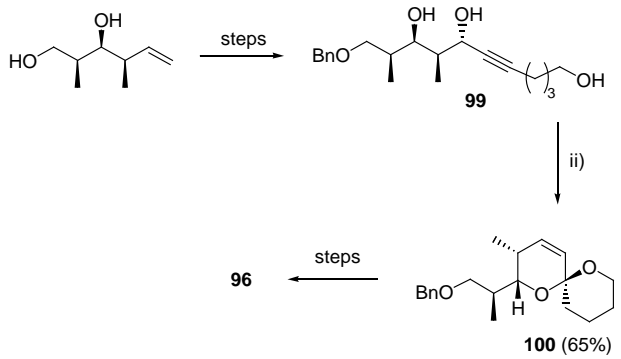

Scheme 28: Synthesis of the C15-C38 fragment of okadaic acid. i) $\mathrm{AuCl}$ (19 mol\%), rt, DCM, then TsOH. $\mathrm{H}_{2} \mathrm{O}, \mathrm{MeOH}$. ii) AuCl (10 5 mol\%), $4 \AA \mathrm{MS}, \mathrm{THF}, 0^{\circ} \mathrm{C}$.

A simple, efficient, and enantiocontrolled synthesis of a near-structural mimic of platensimycin has been accomplished. ${ }^{62}$ This route uses the $\mathrm{AuCl}_{3}$-catalyzed 10 acetalization of a diol, affording the tricyclic core of the natural product in $85 \%$ yield and $>98 \%$ ee after one crystallization from EtOAehexanes.

A synthesis of the trioxadispiroketal-containing A-D rings of the natural product azaspiracid has been developed. It features 15 two different catalytic intramolecular oxametalations to assemble the A-D polyether from acyclic precursors. First, a cobalt-catalyzed oxaetherification was used to form the 2,5trans-fused trisubstituted tetrahydrofuran Dring. Thereafter, a gold(I)-catalyzed bis-spiroketal formation was accomplished 20 using a bridging alkyne as a surrogate for the C10 ketal. This method provided the thermodynamically favored establishment of both of the newly formed spiroketal centers. ${ }^{63}$

\section{Conclusions}

25 In this overview we have collected the most recent advances in gold-catalyzed oxycyclization of alkynols and alkynediols. This type of reactivity has been shown as an established methodology to access to a large number of oxacyclic structures containing different sized skeletons. 30 Furan, pyrans, and different ketals and spiroketal systems are therefore accesible through this strategy. The reactions discussed herein demonstrate the high synthetic potential of alkynols and alkynediols undergoing gold catalyzed cyclization. The extremely high reactivity of gold salts and 35 gold complexes have been also documented in this work, allowing mild reaction conditions and great functional group compatibility, specially compared to related thermal or basic rearrangements. In addition, the unexpected behaviour of this metal-based catalysis promoting new 40 processes will certenely provide more promising results and new routes for organic chemists. Thus, it is believed that the continued and renewed investigation on oxycyclization reactions of alkynols and alkynediols will discover new patterns of reactivity, enabling new sinthetic strategies.

\section{${ }_{45}$ Acknowledgements}

Support for this work by the DGI-MEC (Project CTQ200909318), CAM (Project S2009/PPQ-1752), and SANTANDERUCM (Project GR35/10) are gratefully acknowledged.

\section{Notes and references}

$50{ }^{a}$ Grupo de Lactamas y Heterociclos Bioactivos, Departamento de Química Orgánica I, Unidad Asociada al CSIC, Facultad de Química, Universidad Complutense de Madrid, 28040 Madrid (Spain). Fax: (+34) 91-3944103; Tel: (+34) 91-3944314; E-mail: alcaideb@quim.ucm.es

$55{ }^{\bar{b}}$ Instituto de Química Orgánica General, IQOG, Consejo Superior de Investigaciones Científicas, CSIC, Juan de la Cierva, 3, 28006 Madrid (Spain). Fax: (+34)91-5644853; Tel: (+34) 91-5618806; E-mail: Palmendros@iqog.csic.es

1 (a) A. Fürstner, Chem. Soc. Rev., 2009, 38, 3208-3221; (b) A. Arcadi, Chem. Rev., 2008, 108, 3266-3325; (c) D. J. Gorin, B. D. Sherry and F. D. Toste, Chem. Rev., 2008, 108, 3351-3378; (d) E. Jiménez-Núñez and A. M. Echavarren, Chem. Rev., 2008, 108, 3326-3350; (e) Z. Li, C. Brower and C. He, Chem. Rev., 2008 108, 3239-3265; (f) J. Muzart, Tetrahedron, 2008, 64, 5815-5849; (g) N. T. Patil and Y. Yamamoto, Chem. Rev., 2008, 108, 33953442; (h) R. Skouta and C.-J. Li, Tetrahedron, 2008, 64, 49174918; (i) H. C. Shen, Tetrahedron, 2008, 64, 3885-3903; (j) A. S. K. Hashmi and M. Rudolph, Chem. Soc. Rev., 2008, 37, 17661775; (k) A. Fürstner and P. Davies, Angew. Chem., Int. Ed., 2007, 46, 3410-3449; (l) A. S. K. Hashmi, Chem. Rev., 2007, 107, 31803211; (m) E. Jiménez-Núñez and A. M. Echavarren, Chem. Commun., 2007, 333-346; (n) A. S. K. Hashmi and G. J. Hutchings, Angew. Chem., Int. Ed., 2006, 45, 7896-7936; (o) L. Zhang, J. Sun and S. A. Kozmin, Adv. Synth. Catal., 2006, 348, 2271-2296; (p) M. Malacria, J.-P. Goddard and L. Fensterbank, in Comprehensive Organometallic Chemistry, ed. R. Crabtree and M. Mingos, Elsevier, Amsterdam, $3^{\text {rd }}$ edn, 2006, vol. 10, ch. 10.07, p. 299; (q) R. A. Widenhoefer and X. Han, Eur. J. Org. Chem., 2006, 4555-4563.

2 For selected references on the synthesis of furans, see: (a) X. L Hou, H. Y. Cheung, T. Y. Hon, P. L. Kwan, T. H. Lo, S. Y. Tong H. N. C.Wong, Tetrahedron 1998, 54, 1955-2020. (b) S. J. Cacchi, Organomet. Chem. 1999, 576, 42-64. (c) L. Li, S. Ma, J. Org. 
Chem. 2000, 20, 701-702. (d) S. Ma, Acc. Chem. Res. 2003, 36, 701-707. (e) R. C. D. Brown, Angew. Chem., Int. Ed. 2005, 44, 850-852. (f) S. F. Kirsch, Org. Biomol. Chem. 2006, 4, 2076-2080. (g) D. M. D’Souza, T. J. Muller, J. Chem. Soc. Rev. 2007, 36, 1095-1118. (h) G. Balme, D. Bouyssi, N. Monteiro, Heterocycles 2007, 73, 87-124. (i) X.-L. Hou, Z. Yang, K.-S. Yeung, H. N. C. Wong, Heterocycl. Chem. 2008, 19, 176-207.

3 For recent examples on the synthesis of dihydrofurans, see: (a) M. Ruepig, A. Parra, U. Uxue, F. Besselievre, E. Merino, Org. Lett. 2010, 12, 5680-5683. (b) L. Fan, P. Li, X. Li, D. Xu, M.-M. Ge, W.-D. Zhu, J.-W. Xie, J. Org. Chem. 2010, 75, 8716-8719. (c) S. Maiti, P. Perumal, J. C. Menéndez, Tetrahedron 2010, 66, 95129518. (d) Z. Chen, J. Zhang, Chem. Asian J. 2010, 5, 1542-1545. (e) M. Lau, M. Sher, A. Villiger, C. Fischer, P. Langer, Eur. J. Org. Chem 2010, 19, 3743-3753. (f) Y. Chen, H.-F. Wang, Y. Wang, Y.-C. Luo, H. Zhu, P.-F. Xu, Adv. Synth. Cat. 2010, 352, 1163-1168. (g) M. Brichacek, L. Batorg, J. T. Njardarson, Angew. Chem. Int. Ed. 2010, 49, 1648-1651. (h) M. Brashiolz, H.-U. Reissig, R. Zimmer, Acc. Chem. Res. 2009, 42, 45-56. (i) X.-L. Sun, Y. Tang, Acc. Chem. Res. 2008, 41, 937-948. (j) T.-G. Kilog, T. P. O'Sullivan, P. J. Guiry, Eur. J. Org. Chem. 2005, 23, 49294949.

4 For some selected exaples, see: (a) K. J. Hale, S. Manaviazar, J. George, Chem. Comm. 2010, 46, 4020-4042. (b) K. Kranjc, M Kocevar, Curr. Org. Chem. 2010, 14, 1050-1074. (c) C. J. Forsyth, Asymmetric Synthesis (2 ${ }^{\text {nd }}$ Edition) 2008, 271-276. (d) A. Katritzky, S. Rachwal, Chem. Rev. 2010, 110, 1564-1610. (e) A. Goel, V. J. Ram, Tetrahedron 2009, 65, 7865-7913. For some examples of pyrans in natural products, see: $(f)$ C. Yao, B. Jiang, T. Li, B. Qin, X. Feng, H. Zhang, C. Wang, S. Tu, Bioorg. Med. Chem. Lett. 2011, 21, 599-601. (g) J. S. Yadav, D. Chandrakanth, Y. G. Rao, K. Ravindar, B. V. S. Reddy, Helv. Chim. Acta 2010, 93, 1432-1438. (h) I. Koca, I. Yildirim, E. Sahin, Helv. Chim. Acta 2010, 93, 1336-1343. (i) K. C. Guerard, C. Sabot, M.A. Beaulieu, M.-A. Giroux, S. Canesi, Tetrahedron 2010, 66, 5893-5901. (j) N. Pojchaijongdee, U. Sotanaphun, S. Limsirichaikul, O. Poobrasert, Pharm. Biol. 2010, 48, 740-744. (k) J.-F. Xu, X.-P. Zheng, W.-D. Liu, R.-F. Du, L.-F. Bi, P.-C. Zhang, J. Asian Nat. Prod. Res. 2010, 12, 529-534.

(a) J. McK. R. Woollard, N. B. Perry, R. T. Weavers, J. W. van Klink, Phytochemistry 2008, 69, 1313-1318. (b) Y. Asami, H. Kakeya, R. Onose, A. Yoshida, H. Matsuzaki, H. Osada, Org. Lett. 2002, 4, 2845-2848. (c) O. Ando, H. Satake, M. Nakajima, A. Sato, T. Nakamura, T. Kinoshita, K. Furuya, T. J. Haneishi, Antibiot. 1991, 44, 382-389. (d) S. Kırmızıgul, N. Goren, S.-W. Yang, G. A. Cordell, C. Bozok-Johansson, J. Nat. Prod. 1997, 60, 378-381. (e) H. Shiozawa, M. Takahashi, T. Takatsu, T. Kinoshita, K. Tanzawa, T. Hosoya, K. Furuya, S. Takahashi, K. Furihata, H. J. Seto, J. Antibiot. 1995, 48, 357-362. (f) M. C. Paul, E. Zubia, M. J. Ortega, J. Salvía, Tetrahedron 1997, 53, 2303-2308. (g) R. L. Edwards, D. J. Maitland, C. L. Oliver, M. S. Pacey, L. Shields, A. J. S. Whalley, J. Chem. Soc., Perkin Trans. 1 1999, 715-719. (h) T. Koga, K. Moro, T. Matsudo, J. Agric. Food Chem. 1998, 46, 946-951. (i) H. Oh, S. Lee, H.-S. Lee, D.-H. Lee, S. Y. Lee, H.-T. Chung, T. S. Kim, T.-O. Kwon, Phytochemistry 2002, 61, 175179. (j) H. Heaney, J. S. Ahn, In Comprehensive Heterocyclic ChemistryII; Katritzky, A. R., Rees, C. W., Scriven, E. F. V., Eds.; Pergamon Press: Oxford, 1996; Vol. 2, pp 297-436. (k) B. König In Science of Synthesis, Houben-Weyl Methods of Molecular Transformations; Maas, G., Eds.; Georg, Thieme Verlag: Stuttgart, 2001; Vol. 9, pp 183-285. (l) T. Eicher, S. Hauptmann, In The Chemistry of Heterocycles: Structure, Reactions, Syntheses, and Applications; Eds.; Wiley-VCH: Weinheim, 2003. (m) B. H. Lipshutz, Chem. Rev. 1986, 86, 795-820.

6 For recent examples on ketal synthesis and biological activity, see: (a) ref 4 (c). (b) S. Mahalinngam, B. K. Mishra, H. N. Pati, Org. Chem. I. J. 2009, 5, 111-116. (c) R. Ballini, M. Petrini, Arkivoc 2008, 9, 195-223. (d) C. J. Forsyth, Asymmetric Synthesis Ed. M. Christmann, S. Braese, Wiley-VCH Verlag Gmbh \& Co, Weinheim, Germany, 2007, 256-261. (e) B. D. Sherry, L. Maus, B.
N. Laforteza, D. F. Toste, J. Am. Chem. Soc. 2006, 128, 81328133.

7 For some recent examples see: (a) S. M. Couvertier, K. J. Quinn, Abstracts of Papers, 239th ACS National Meeting, San Francisco, CA, United States, March 21-25, 2010. (b) L. Islamaj, K. E. Shanley, K. J. Quinn, Abstracts of Papers, 239th ACS National Meeting, San Francisco, CA, United States, March 21-25, 2010. (c) W.-S. Feng, H. Chen, X.-K. Zheng, Y.-Z. Wang, L. Gao, H.-W. Li, J. Asian Nat. Prod. Research 2009, 11, 658-662. (d) L. A. R. dos Santos Lima, L. Pimenta, M. A. D. Boaventura, Planta Medica 2009, 75, 80-83. (e) F. Volz, S. H. Wadman, A. HoffmannRoeder, N. Krause, Tetrahedron 2009, 65, 1902-1910. (f) H. Kim, A. C. Kasper, E. J. Moon, Y. Park, C. M. Wooten, M. W. Dewhirst, J. Hong, Org. Lett. 2009, 11, 89-92. (g) J.-F. Hu, C. M. Starks, E. Garo, G. W. Hough, S. M. Rice, M. G. Goering, M. O'Neil-Johnson, G. R. Eldridge, J. Chem. Res. 2008, 20-21. (h) M. D. Mihovilovic, D. A. Bianchi, F. Rudroff, Chem. Comm. 2006, 30, 3214-3216.

8 (a) I. M. Heilbron, E. R. Jones, P. Smith, B. C. L. Weedon, J. Chem. Soc. 1946, 54; (b) R. Wiley, C. H. Jarboe, F. N. Hayes, J. Am. Chem. Soc. 1957, 79, 2602-2605; (c) M. Riediker, J. Schwartz, J. Am. Chem. Soc. 1982, 104, 5842-5844; (d) M. Suzuki, A. Yanagisawa, R. Noyori, Tetrahedron Lett. 1983, 24, 11871188. (e) K. Utimoto, Pure Appl. Chem. 1983, 55, 1845-1852; $(f)$ P. Compain, J. Goré, J.-M. Vatèle, Tetrahedron 1996, 52, 10405 10416. (g) P. Pale, J. Chuche, Tetrahedron Lett. 1986, 28, 66476648; (h) P. Pale, J. Chuche, Eur. J. Org. Chem. 2000, 1019-1025. (i) F. Mc Donald, M. M. Gleason, J. Am. Chem. Soc. 1996, 118, 6648-6659. (j). E. Genin, S. Antoniotti, V. Michelet, J.-P. Genet, Angew. Chem., Int. Ed. 2005, 44, 4949-4953.

9 V. Dalla, P. Pale, New J. Chem. 1999, 23, 803-805.

10 H. Harkat, J.-M. Weibel, P. Pale, Tetrahedron Lett. 2007, 48, 1439-1442.

11 For the isolation of vinylgold complexes, see: (a) L.-P. Liu, B. Xu, M. S. Mashuta, G. B. Hammond, J. Am. Chem. Soc. 2008, 130 , 17642-17643. (b) A.S.K. Hashmi, A. M. Schuster, F. Rominger, Angew. Chem. Int. Ed. 2009, 48, 8247-8249.

12 A. M. Manzo, A. Perboni, G. Broggini, M. Rigamonti, Synthesis 2011, 127-132

13 J. C. Jury, N. K. Swamy, A. Yazici, A. C. Willis, S. G. Pyne, J. Org. Chem. 2009, 74, 5523-5527.

14 C. Laroche, S. M. Kerwin, J. Org. Chem. 2009, 74, 9229-9232.

15 (a) R. Rüttinger, J. Leutzow, M. Wilsdorf, K. Wilckens, C. Czekelius, Org. Lett. 2011, 13, 224-227. (b) K. Wilckens, M. Uhlemann, C. Czekelius, Chem. Eur. J. 2009, 15, 13323-13326.

16 J. K. De Brabander, B. Liu, M. Qian, Org. Lett. 2008, 10, 2533 2536.

17 H. H. Jung, P. E. Floreancig, Org. Lett. 2006, 8, 1949-1951.

18 A. S. K. Hashmi, L. Schwarz, J.-H. Choi, T. M. Frost, Angew. Chem. Int. Ed. 2000, 39, 2285-2288.

19 Y. Liu, F. Song, Z. Song, M. Liu, B. Yan, Org. Lett. 2005, 7, 54095412.

20 A. S. K. Hashmi, T. Häffner, M. Rudolph, F. Rominger, Eur. J. Org. Chem. 2011, 667-671.

21 (a) J. A. Marshall, W. J. Dubay, J. Org. Chem. 1993, 58, 34353443. (b) J. A. Marshall, C. E. Bennett, J. Org. Chem. 1994, 59, 6110-6113. (c) J. A. Marshall, W. J. Dubay, J. Org. Chem. 1994, 59, $1703-1708$

22 (a) B. Seiller, C. Bruneau, P. H. Dixneuf, J. Chem. Soc., Chem. Commun. 1994, 493-496. (b) H. Kücükbay, B. Cetinkaya, I. Özdemir, C. Bruneau, P. H. Dixneuf, J. Mol. Catal. 1997, 118, L1L4. (c) B. Seiller, C. Bruneau, P. H. Dixneuf, Tetrahedron 1995, 51, 13089-130120.

23 B. Gabriele, G. Salerno, E. Lauria, J. Org. Chem. 1999, 64, 76877692.

24 For selected examples, see: (a) P. J. Jerris, A. B. Smith, J. Org. Chem. 1981, 46, 577-585. (b) S. Chimichi, M. Boccalini, B. Cosimelli, F. Dall'Acqua, G. Viola, Tetrahedron 2003, 59, 52155223. (c) S. W. Felman, I. Jirkovski, K. A. Memoli, L. Borella, C. Wells, J. Russell, J. Ward, J. Med. Chem. 1992, 35, 1183-1190. (d) 
R. A. Mack, W. I. Zazulak, L. A. Radov, J. E. Baer, J. D. Stewart, P. H. Elzer, C. R. Kinsolving, V. S. J. Georgiev, J. Med. Chem. 1988, 31, 1910-1918. (e) S. S. Shin, Y. Byun, K. M. Lim, J. K. Choi, K.- W. Lee, J. H. Moh, J. K. Kim, Y. S. Jeong, J. Y. Kim, Y. H. Choi, H.- J. Koh, Y.-H. Park, Y. I. Oh, M.-S. Noh, S. Chung, J. Med. Chem. 2004, 47, 792-804. (f) A. Carotti, A. Carrieri, S. Chimichi, M. Boccalini, B. Cosimelli, C. Gnere, A. Carotti, P.-A. Carrupt, B. Testa, Bioorg. Med. Chem. Lett. 2002, 12, 3551-3555.

25 For some examles, see: (a) Ref. $22(a)$. (b) Ref. $22(b)$. (c) A. B. Smith, P. A. Levenberg, P. J. Jerris, R. M. Scarbourgh, P. M. Wovkulich, J. Am. Chem. Soc. 1981, 103, 1501-1513. (d) S. Manfredini, P. G. Baraldi, R. Bazzanini, M. Guarneri, D. Simoni, J. Balzarini, E. De Clercq, J. Med. Chem. 1994, 37, 2401-2405. (e) J. D. Winkler, K. Oh, S. M. Asselin, Org. Lett. 2005, 7, 387-389. (f) P. Langer, T. Krummel, Chem. Commun. 2000, 967-968. (g) D. Villemin, P.-A. Jaffrès, M. Hachémi, Tetrahedron Lett. 1997, 38, 537-538. (h) B. Crone, S. F. Kirsch, J. Org. Chem. 2007, 72, 54355438. (i) Y. Liu, M. Liu, S. Guo, H. Tu, Y. Zhou, H. Gao, Org. Lett. 2006, 8, 3445-3448. (j) C. M. Marson, E. Edaan, J. M. Morrell, S. J. Coles, M. B. Hursthouse, D. T. Davies. Chem. Commun. 2007, 2794-2496.

26 M. Egi, K. Azechi, M. Saneto, K. Shimizy, S. Akai, J. Org. Chem. 2010, 75, 2123-2126.

27 L. Ye, L. Cui, G. Zhang, L. Zhang, J. Am. Chem. Soc. 2010, 132, 3258-3259.

28 L. Ye, W. He, L. Zhang, J. Am. Chem. Soc. 2010, 132, 8550-8551.

29 (a) L. F. Tietze, G. Brasche, K. Gericke in Domino Reactions in Organic Synthesis, Wiley-VCH, Weinheim, 2006. (b) K. C. Nicolau, E. W. Yue, T. Oshima in The New Chemistry (Ed.; N. Hall), Cambridge University Press, Cambridge, 2001, pp. 168. (c) L. F. Tietze, U. Beifuss, Angew. Chem. Int. Ed. Engl. 1993, 32, 131-163.

30 For some selected examples, see: (a) J. Barluenga, A. Fernández, A. Diéguez, F. Rodríguez, F. J. Fañanás, Chem. Eur. J. 2009, 15, 11660-11667. (b) J. Barluenga, A. Fernández, F. Rodríguez, F. J. Fañanás, Chem. Eur. J. 2009, 15, 8121-8123. (c) J. Barluenga, A. Fernández, F. Rodríguez, F. J. Fañanás, Organomet. Chem. 2009, 694, 546-550. (d) F. J. Fañanás, A. Fernández, D. Çevic, F. Rodríguez, J. Org. Chem. 2009, 74, 932-934. (e) A. DiéguezVázquez, C. C. Tzschucke, W. Y. Lam, S. V. Ley, Angew. Chem. Int. Ed. 2008, 47, 209-212. (f) B. Liu, J. K. De Brabander, Org. Lett. 2006, 8, 4907-4910. (g) V. Belting, N, N. Krause, Org. Lett. 2006, 8, 4489-4492.

31 For application on organic synthesis, see: (a) C. G. Krause, N. L. J. M. Broekhof, A. Van der Gen, Tetrahedron Lett. 1976, 20, 17251728. (b) M. Ochiai, T. Sueda, Tetrahedron Lett. 2004, 45, 35573559. For biological activity, see: (c) Y.-H. Kuo, Y.-J. Kuo, A.-S. Yu, M.-D. Wu, C.-W. Ong, L.-M. Yang, J.-T. Huang, C.-F. Chen, S.-Y. Li, Chem. Pharm. Bull. 2003, 51, 425-426. (d) M. W. Biavatti, P. C. Vieira, M. F. G. F. Da Silva, J. B. Fernandes, S. Alburquerque, J. Nat. Prod. 2001, 65, 562-565.

32 V. Belting, N. Krause, Org. Lett. 2006, 8, 4482-4492.

33 B. Alcaide, P. Almendros, T. Martínez del Campo, R. Carrascosa, Eur. J. Org. Chem. 2010, 4912-4919.

34 For selected examples, see: (a) Z. Zhang, Q. Zhang, Z. Ni, Q. Liu, Chem. Commun. 2010, 46, 1269-1271. (b) E. Leemans, M. D'hooghe, Y. Dejaegher, K. W. Törnroos, N. De Kimpe, Eur. J. Org. Chem. 2010, 352-358. (c) A. Al-Harrasi, F. Pfrengle, V. Prisyazhnyuk, S. Yekta, P. Kóos, H.-U. Reissig, Chem. Eur. J. 2009, 15, 11632-11641. (d) A. Koziol, B. Furman, J. Frelek, M. Woznica, E. Altieri, M. Chmielewski, J. Org. Chem. 2009, 74, 5687-5690. (e) B. Alcaide, P. Almendros, T. Martínez del Campo, E. Soriano, J. L. Marco-Contelles, Chem. Eur. J. 2009, 15, 19011908.

35 N. T. Patil, R. D. Kavthe, V. S. Raut, V. S. Shinde, B. Sridhar, J. Org. Chem. 2010, 75, 1277-1280.

36 (a) N. Y. Patil, V. Singh, A. Konala, A. K. Mutyala, Tetrahedron Lett. 2010, 51, 1493-1496. (b) N. T. Patil, A. Konala, Eur. J. Org. Chem. 2010, 6831-6839.
37 J. Barluenga, J. Calleja, A. Mendoza, F. Rodríguez, F. J. Fañanás, Chem. Eur. J. 2010, 16, 7110-7112.

38 L.-P. Liu, G. B. Hammond, Org. Lett. 2010, 12, 4640-4643.

39 L. Zhang, S. A. Kozmin, J. Am. Chem. Soc. 2005, 127, 6962-6963.

40 S. Kim, D. Kang, S. Shin, P. H. Lee, Tetrahedron Lett. 2010, 51, 1899-1901.

41 X. Zhang, Z. Lu, C. Fu, S. Ma, J. Org. Chem. 2010, 75, 25892598.

42 S. Antoniotti, E. Genin, V. Michelet, J.-P. Genêt, J. Am. Chem. Soc. 2005, 127, 9976-9977.

43 (a) D. N. Kumar, B. Rao, G. S. Ramanjaneyulu, Tetrahedron: Assymetry 2005, 16, 1611-1614. (b) H. Suga, K. Inoue, A. Kakechi, M. Shiro, J. Org. Chem. 2005, 70, 47-56. (c) G. M. Strunz, C.-M. Yu, L. Ya, P. S. White, E. A. Dixon, Can. J. Chem. 1990, 68, 782-786. (d) N. Ibrahim, T. Eggigann, E. A. Dixon, H. Wieser, Tetrahedron 1990, 46, 1503-1514.

44 L.-P. Liu, G. B. Hammond, Org. Lett. 2009, 11, 5090-5092.

45 B. Liu, J. K. De Brabander, Org. Lett. 2006, 8, 4907-4910.

46 A. Aponick, C.-Y. Li, J. A. Palmes, Org. Lett. 2009, 11, 121-124.

47 A. S. Hashmi, M. Bührle, M. Wölfe, M. Rudolph, M. Wieteck, F. Rominger, W. Frey, Chem,. Eur. J. 2010, 16, 9846-9854.

48 M. Egi, K. Azechi, S. Akai, Org. Lett. 2009, 11, 5002-5005.

49 Y. Zhang, J. Xue, Z. Xin, Z. Xie, Y. Li, Synlett 2008, 940-944.

50 For a review see: A. Boumenjel, Curr. Med. Chem. 2003, 10, 2621-2330.

51 (a) C. J. W. Brooks, D. G. Watson, Nat. Prod. Rep. 1985, 427-459. (b) M. Morimoto, H. Fukumoto, T. Nozoe, A. Hagiwara, K. Komai, J. Agric. Food Chem. 2007, 55, 700-705. (c) S. Okombi, D. Rival, S. Bonnet, A.-M. Mariotte, E. Perrier, A. Boumendjel, $J$. Med. Chem. 2006, 49, 329-333. (d) S. Venkateswarlu, G. K. Panchagnula, G. V. Subbaraju, Biosci. Biotechnol. Biochem. 2004, 68, 2183-2185. (e) M. Auf'mkolk, J. Koerhle, R. D. Hesch, V. Cody, Biol. Chem. 1986, 261, 11623-11630.

52 (a) J. A. Donnelly, M. J. Fox, T. C. Sharma, Tetrahedron 1979, 35, 875-879. (b) G. Bose, E. Mondal, A. T. Khan, M. J. Bordoloi, Tetrahedron Lett. 2001, 42, 8907-8909. (c) A. Lévai, A. L. Tökés, Synth. Comm. 1982, 12, 701-707. (d) K. Imafuku, M. Honda, J. F. W. McOmie, Synthesis 1987, 199-201. (e) H. Sekizaki, Bull. Chem. Soc. Jpn. 1988, 61, 1407-1409. (f) K. Thakkar, M. Cushman, J. Org. Chem. 1995, 60, 6499-6510. (g) Z.-W. An, M. Catellani, G. P. Chiusoli, J. Organomet. Chem. 1990, 397, 371373. (h) T.-T. Jong, S.-J. Leu, J. Chem. Soc., Perkin Trans I 1990, 423-424. (i) R. S. Varma, M. Varma, Tetrahedron Lett. 1992, 33, 5937-5940.

53 H. Harkat, A. Blanc, J.-M. Weibel, P. Pale, J. Org. Chem. 2008, 73, 1620-1623.

54 Atta-ur-Rahman. M. I. Choudhary, S. Hayat, A. Khan, A. Ahmed, Chem. Pharm. Bull. 2001, 49, 105-107.

55 S. Kobayashi, T. Miyase, H. Noguchi, J. Nat. Prod. 2002, 65, 319328.

56 B. M. Trost, G. Dong, J. Am. Chem. Soc. 2010, 132, 16403-16416.

57 For other information on bryostatin 16, see: G. R. Pettit, F. Gao, P. M. Blumberg, C. L. Herald, J. C. Coll, Y. Kamano, N. E. Lewin, J. M. Schmidt, J.-C. Chapuis, J. Nat. Prod. 1996, 59, 286-289.

58 For some selected reviews and reports, see: (a) K. J. Hale, M. G. Hummersome, S. Manaviazar, M. Frigerio, Nat. Prod. Rep. 2002, 19, 413-453. (b) D. J. Newman, G. M. Cragg, J. Nat. Prod. 2004, 67, 1216-1238. (c) R. Etcheberrigaray, M. Tan, L. Dewwatcher, C. Kuipert, L. Van der Auwera, S. Wera, L. Qtao, B. Bank, T. J. Nelson, A. P. Kozikowski, F. Van Leuven, D. L. Alkon, Proc. Natl. Acad. Sci. U. S. A. 2004, 101, 11141. (d) J. Hongpalsan, D. L. Alkon, Proc. Natl. Acad. Sci. U. S. A. 2007, 104, 19571.

59 (a) K. Tachibana, P. J. Scheuer, Y. Tsukitamni, H. Kikuchi, D. Van Engen, J. Clardy, Y. Gopichand, F. J. Schimtz, J. Am. Chem. Soc. 1981, 103, 2469-2471. (b) A. B. Dounay, C. J. Forsyth, Curr. Med. Chem. 2002, 9, 1851-1858.

60 (a) P. Scheuer, J. Nat. Prod. 1995, 58, 335-343. (b) T. Yasumoto, M. Murata, Y. Oshima, M. Sano, G. K. Matsumoto, J. Clardy, Tetrahedron 1985, 41, 1019-1022. (c) C. Bialojan, A. Takai, Biochem. J. 1988, 256, 283-290. 
61 C. Fang, Y. Pang, C. Forsyth, Org. Lett. 2010, 12, 4528-4531.

62 Y.-Y. Yeung, E. J. Corey, Org. Lett. 2008, 10, 3877-3878.

63 Y. Li, F. Zhou, C. J. Forsyth, Angew. Chem. Int. Ed. 2007, 46, 279-282.

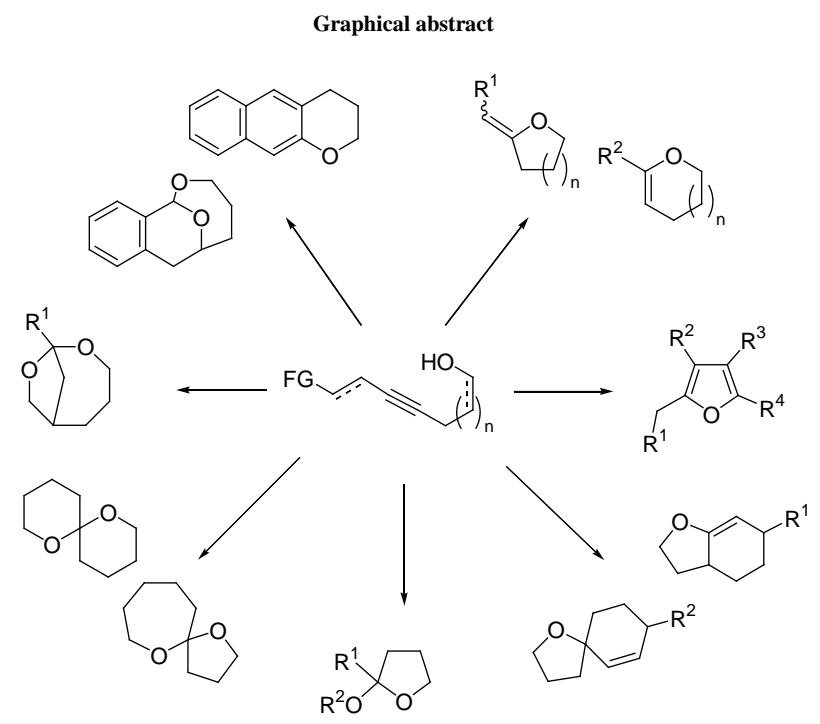

Alkynols and alkynediols represent excellent building blocks for oxycyclizations, leading to a large number of different cyclic structures in one single step.

Alcaide, B.; Almendros, P.; Alonso, J. M.

Título: Gold Catalyzed Oxycyclizations of Alkynols and Alkyndiols

Revista: Org. Biomol. Chem. 2011, 9, 44054416 